\title{
Responsabilidad de los administradores de las sociedades cooperativas en situación de disolución forzosa
}

Responsibility of the administrators of the cooperative societies in a situation of forced dissolution

\author{
Responsabilidade dos gerentes da empresa cooperativas \\ em situação de dissolução forçada
}

\section{Daniel Rodríguez Ruiz de Villa* María Isabel Huerta Viesca**}

Recibido: 10 de agosto de 2018 Aceptado: 22 de octubre de 2018 Publicado: 5 de abril de 2019

Cómo citar este artículo:

Rodríguez Ruíz, D. y Huerta Viesca, M. (2019). Responsabilidad de los administradores de las sociedades cooperativas en situación de disolución

forzosa. Cooperativismo \& Desarrollo, 27(1), 1-38. doi: https://doi.org/10.16925/2382-4220.2019.01.08

Artículo de investigación. https://doi.org/10.16925/2382-4220.2019.01.08

* Universidad de Oviedo, Austrias. España. correo electrónico: ruizvilla@infonegocio.com

** Universidad de Oviedo, España.

Correo electrónico: ishuerta@uniovi.es 


\section{Resumen}

Este artículo presenta el análisis y sistematización de la legislación autonómica española en materia de responsabilidad de administradores de sociedades cooperativas incursas en causas de disolución forzosa. Igualmente, un estudio de la legislación estatal sobre la cuestión. Una propuesta de armonización y mejora de las leyes estatales y autonómicas, con el objetivo de garantizar un régimen jurídico uniforme, aplicable también a la Sociedad Cooperativa Europea domiciliada en cualquier lugar de España.

Palabras clave: administradores, disolución forzosa, disolución judicial. Responsabilidad. Sociedad cooperativa europea. Sociedades cooperativas.

\section{Abstract:}

This article presents the analysis and systematization of the Spanish regional legislation concerning liability of managers of cooperative societies when cases of forced dissolution. Similarly, a study of State Laws on the issue. A proposal for harmonization and improvement of regional and State Laws to ensure a uniform legal regime applicable also to European cooperative Society domiciled anywhere in Spain.

Keywords: Administrators, forced dissolution, judicial dissolution. Liability. European Cooperative Society. Cooperative Societies

\section{Resumo}

Este artigo apresenta a análise e sistematização da legislação autonômica espanhola em matéria de responsabilidade de administradores de sociedades cooperativas incorre em causas de dissolução forçada. Da mesma forma, um estudo da legislação estadual sobre o assunto. Uma proposta de harmonização e melhoria das leis estaduais e regionais, com o objectivo de garantir um regime jurídico uniforme, também aplicável à Sociedade Cooperativa Europeia domiciliado em qualquer lugar da Espanha.

Palavras-chave: administradores, dissolução forçada, dissolução judicial. Responsabilidade Sociedade Cooperativa Europeia, Sociedades cooperativas. 


\section{Justificación del estudio}

De todos es conocido que uno de los temas más interesantes, complejos y debatidos en la práctica del derecho de sociedades español de las últimas dos décadas ha sido el de la responsabilidad de los administradores de las sociedades de capital incursas en causas de disolución forzosa. Especialmente respecto de las incursas en pérdidas patrimoniales agravadas o en situación de insolvencia'. A lo anterior ha colaborado el legislador español en la última década, con dos sucesivas reformas en brevísimo espacio de tiempo de los preceptos que regulan dicho régimen, en particular de los artículos 260 y 262 LSA de 1989 y 104 y 105 LSRL de 1995², luego refundidos en los artículos 363 y 365 TRLSC $^{3}$ y más tarde retocado el primero de estos últimos por la Ley 25/2011, de 1 de agosto ${ }^{4}$. Durante este constante peregrinar de normas, cuando se estaba empezando a asimilar la última reforma de finales de 2005; en 2006, el legislador ya tenía en trámite una nueva reforma, la contenida en el apartado diez del artículo segundo y en el apartado tres del artículo tercero del Proyecto de Ley de reforma y adaptación de la legislación mercantil en materia contable para su armonización internacional con base en la normativa de la Unión Europea ${ }^{5}$. Y por si esa sucesiva incidencia de reformas directas no fuera suficiente no hay que olvidar la incidencia de las sucesivas reformas de la legislación concursal y paraconcursal de los años 2008, 2009 y 2011, con incidencia directa en la responsabilidad de los administradores -fundamentalmente los Reales Decretos-Leyes 10/2008 y 3/2009 y la Ley 38/2011, de 10 de octubre-.

Afortunadamente, estos últimos años han sido de mayor sosiego legislativo, lo que ha permitido una mínima sedimentación de la normativa aplicable. Al tiempo, ha

1 Para una referencia más amplia aparte de otras modalidades de responsabilidad de los administradores de las sociedades cooperativas, ver: Morillas Jarillo, M.J., "La responsabilidad de los administradores de las Sociedades Cooperativas: mosaico legal e interpretación judicial", Ciriec-España, Revista Jurídica, 28. Disponible en: http://www.ciriec-revistajuridica.es/index. php?id_pagina=8\&idRevista=31.

2 Nos referimos en concreto a las reformas fruto de las disposiciones finales vigésima y vigésima primera de la Ley 22/2003, de 9 de julio, concursal, y de las disposiciones finales primera y segunda de la Ley 19/2005, de 14 de noviembre, de la Sociedad Anónima Europea domiciliada en España.

3 Texto refundido de la Ley de Sociedades de Capital, aprobado por Real Decreto Legislativo $1 / 2010$, de 2 de julio, y en vigor desde el 1 de septiembre de 2010.

4 Ley $25 / 2011$, de 1 de agosto, de Reforma parcial de la Ley de Sociedades de Capital (RCL 2010\1792, 2400) y de incorporación de la Directiva 2007/36/CE, del Parlamento Europeo y del Consejo, de 11-7-2007, sobre el ejercicio de determinados derechos de los accionistas de sociedades cotizadas

5 Ver de manera ampliada el proyecto de Ley 121/000086, Boletín Oficial de las Cortes Generales. Congreso de los Diputados, VIII Legislatura, Serie A: Proyectos de Ley, 12 de mayo de 2006, núm. 86-1. 
facilitado que las aportaciones jurisprudenciales se produzcan sobre normativa en vigor, no ya derogada, como venía ocurriendo en años anteriores.

Partiendo de la complicada situación normativa que se acaba de referir en el ámbito del derecho de las sociedades de capital y teniendo en cuenta el influjo que su régimen jurídico tiene sobre las cooperativas, es interesante y complejo el análisis del mismo tema en las citadas sociedades cooperativas. En este último caso, la cuestión requiere analizar el laberíntico régimen jurídico español de las cooperativas, que combina la legislación estatal y la legislación de aquellas comunidades autónomas, casi todas han legislado sobre esta materia, con la incidencia directa también del derecho comunitario - sociedad cooperativa europea-.

\section{Sistematización de las leyes autonómicas en materia de responsabilidad de administradores de sociedades cooperativas en causa de disolución forzosa}

El estudio de las quince leyes autonómicas actualmente vigentes en otras tantas comunidades autónomas españolas -todas salvo Canarias y Cantabria- ${ }^{6}$, conduce, para aliviar el esfuerzo de su comprensión, a la necesidad imperiosa de sistematizar las mismas a la hora de regular la responsabilidad de los administradores de las cooperativas en causa de disolución forzosa. El criterio de ordenación que se ha seguido es el de asimilar entre sí, y en la mayor medida posible, los diferentes regímenes ordenadamente, partiendo de los más exigentes para los administradores para llegar a los menos exigentes.

Así, cabe hablar, y pese al esfuerzo sistematizador referido, de cinco grandes sistemas autonómicos - dejamos aparte el sistema autonómico asturiano, que estudiaremos separadamente-, en función de que contengan:

6 Para una referencia sistemática de las mismas, desde una lógica perspectiva crítica en términos de ciencia de la legislación, por encontrarnos ante una especie de competición atlético-normativa entre las diversas Comunidades Autónomas, por ejemplo, Paniagua Zurera, "Las empresas de inserción en la Ley estatal 44/2007, de 13 de diciembre, reguladora de las empresas de inserción", $C D C, 49$, junio (2008). En esa competición atlético-normativa tendríamos el récord mundial porque, como destaca Vicent Chulià, F., Introducción al Derecho mercantil (2012a) "es el único país del mundo donde se produce esta multiplicación de leyes cooperativas, sin una ventaja visible para éstas". 
1. La previsión de un régimen especialísimo de responsabilidad de los administradores para el supuesto de no disolución o transformación forzosa en el plazo de seis meses contados desde que sea ejecutiva la resolución administrativa de descalificación de la cooperativa -artículos 141.4 de la Ley 4/1993, de 24 de junio, que regula las cooperativas del País Vasco, 135.4 de la Ley 4/1999, de 30 de marzo, de normas reguladoras de las cooperativas de la Comunidad Autónoma de Madrid, 139.4 de la Ley 20/2002, de 14 de noviembre, de cooperativas de Castilla-La Mancha y 121.2.3 de la Ley 8/2003, de 24 de marzo, de cooperativas de la Comunidad Valencia-.

Con mínimas diferencias de redacción, los preceptos citados previenen que los administradores -junto con los directores o gerentes y, en su caso, liquidadores de la cooperativa - responderán solidariamente entre sí y con la cooperativa de las deudas sociales. De ese régimen general se aparta, aun manteniendo la misma responsabilidad personal y solidaria de los miembros del Consejo Rector entre sí y con la sociedad, el artículo 141.3 de la Ley 8/2006, de 16 de noviembre, de Sociedades Cooperativas de la Región de Murcia. Este artículo elimina el antes citado plazo de seis meses, de modo que la responsabilidad nace con la firmeza de la descalificación, y delimita el ámbito objetivo de la responsabilidad para comprender sólo las deudas sociales generadas tras la incoación del procedimiento de descalificación.

Se trata, en todos los supuestos referidos, de un ejemplo más de responsabilidad-sanción, en línea con el primitivo artículo 262.5 LSA, que sanciona a los administradores de la cooperativa con su responsabilidad solidaria por todas las deudas sociales. Bien sean anteriores o posteriores al hecho desencadenante de su responsabilidad, salvo en el antes citado caso de la Región de Murcia, puesto que ubi lex non distinguet nec nos distinguere debemus.

2. La previsión de un régimen especial de responsabilidad de los administradores para el caso de no convocatoria de Asamblea General de disolución o de no solicitud de disolución judicial -así, el artículo 95.2, 4 y 5 de la Ley de Cooperativas de la Comunidad Autónoma de Madrid, el artículo 92.5 de la

7 En la doctrina, Morillas Jarillo, M. J. y M. I. Feliú Rey, Curso de Cooperativas (2002), entienden que conduce a la misma situación la interpretación integradora de los artículos 54.2 de la Ley de Cooperativas de La Rioja y 51 de la Ley de Cooperativas de Castilla y León. Respecto de esta última, la Sentencia de Sección $3^{\text {a }}$ de la Audiencia Provincial de Valladolid de 28 de diciembre de 2010 (Ponente: Iltmo. Sr. D. Miguel Ángel Sendino Arenas; Jur. 2011/68981), que entiende que el citado precepto legal sólo remite a las acciones individual y social de responsabilidad. 
Ley de Cooperativas de Castilla-La Mancha', sustituido en la actualidad, en el mismo sentido, por la nueva Ley de Cooperativas de Castilla-La Mancha de 4 de noviembre de 2010, artículo 112.5; el artículo 97.4 de la Ley 8/2006, de 16 de noviembre, de Sociedades Cooperativas de la Región de Murcia ${ }^{9}$ y el artículo 79.3 de la Ley 14/2011, de 23 de diciembre, de Sociedades Cooperativas Andaluzas, desarrollado en el artículo 67 del Decreto 123/2014, de 2 de septiembre, por el que se aprueba el Reglamento de la Ley 14/2011, de 23 de diciembre, de Sociedades Cooperativas Andaluzas ${ }^{10}$.

8 En aplicación específica de este precepto, en línea con los artículos 262.5 LSA y 105.5. LSRL, vid. la Sentencia de la Sección $2^{\text {a }}$ de la Audiencia Provincial de Ciudad Real de 9 de diciembre de 2008 (Ponente: Iltma. Sra. $D^{a}$. Carmen Pilar Catalán Martín de Bernardo; Id Cendoj: 13034370022008100464).

9 Aplicado en la práctica en las Sentencias de la Sección $4^{\text {a }}$ de la Audiencia Provincial de Murcia de 14 de octubre de 2010 (Ponente: Iltmo. Sr. D. Juan Martínez Pérez; AC 2010/1790), del Juzgado de lo Mercantil no 2 de Murcia de 2 de marzo de 2016 (Iltmo. Sr. D. Francisco Cano Marco; Id Cendoj: 3003047002016100032) y de la Sección $4^{\text {a }}$ de la Audiencia Provincial de Murcia de 19 de octubre de 2017 (Ponente: Iltmo. Sr. D. Rafael Fuentes Devesa; Id Cendoj: 30030370042017100673).

10 Sensu contrario vid. la Sentencia de la Sección $6^{\text {a }}$ de la Audiencia Provincial de Málaga de 18 de junio de 2014 (Ponente: Iltma. Sra. Da . Nuria Auxiliadora Orellana Cano; Id Cendoj: 29067370062014100441): "En síntesis, consideramos que no resulta aplicable la normativa de sociedades anónimas sobre responsabilidad por deudas a las cooperativas andaluzas a las que se les aplica la Ley de Cooperativas Andaluzas de 1999. Primero, porque ni la normativa autonómica ni la estatal prevén expresamente la responsabilidad por deudas. Segundo, porque no cabe hacer una interpretación extensiva de la remisión que el artículo 43 de la Ley 27/1999, de 16 de julio, de Cooperativas hace a la Ley de Sociedades Anónimas, por el carácter sancionador de dicha responsabilidad, limitándose la remisión a la aplicación de la normativa societaria sobre responsabilidad por daños. Tercero, por la propia ubicación sistemática de dicha remisión en sede de responsabilidad de los miembros del Consejo rector, no ubicada en el precepto relativo a disolución de la sociedad, que es la sede en la que se regula la responsabilidad por deudas, tanto en la normativa societaria, como en las normativas autonómicas que expresamente contemplan la responsabilidad por no disolver la sociedad. Cuarto, porque la nueva Ley de Sociedades Cooperativas Andaluzas de 23 de diciembre de 2011 expresamente recoge dicha responsabilidad en el artículo 79, y la normativa anterior no contenía un precepto similar". En similar sentido, posteriormente, las sentencias de la

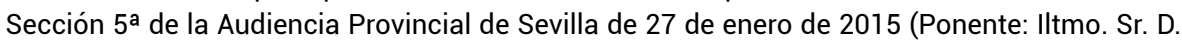
José Herrero Tagua; Id Cendoj: 41091370052015100035$)$ y de 16 de julio de 2015 (Ponente: Iltmo. Sr. D. Gonzalo Gallardo Correa; Id Cendoj: 41091370052015100276$)$-respecto de las que se inadmitieron sendos recursos de casación por los Autos de la Sala $1^{\text {a }}$ del Tribunal Supremo de 1 de marzo de 2017 (Ponente: Excmo. Sr. D. Antonio Salas Carceller; Id Cendoj: 28079110012017200536 ) y de 24 de enero de 2018 (Ponente: Excmo. Sr. D. Francisco Marín Castán; Id Cendoj: 28079110012018200242$)$, respectivamente, interpuestos además sólo respecto de sus pronunciamientos de condena por responsabilidad individual, no por deudas-, y reconduciendo la responsabilidad de los administradores a una responsabilidad por daños, que identifica como los créditos no recuperados por un socio, en una cooperativa andaluza en la que, además, sus estatutos obligaban a los administradores a convocar asamblea general para la disolución y, en su caso, a instar la disolución judicial, vid. la Sentencia de la Sección $5^{\text {a }}$ de la Audiencia Provincial de Sevilla de 16 de febrero de 2015 (Ponente: Iltmo. Sr. D. José Herrero Tagua; Id Cendoj: 41091370052015100062). 
Este régimen es el que más se asimila dentro de los autonómicos, como se verá más adelante, al nacional de las sociedades de capital. Conforme al artículo 95.2 de la Ley de Madrid, el órgano de administración de la cooperativa tiene la obligación de convocar Asamblea General de disolución dentro del plazo de los treinta días. Los citados treinta días hay que entender que son hábiles por expresa previsión de la disposición adicional segunda de la Ley de Cooperativas de Madrid. Por otro lado, no se concreta la fecha de inicio del cómputo de tal plazo, por ello hay que entender que habrá de ser aquélla en que los administradores debieron conocer la existencia de la causa de disolución forzosa, de acuerdo con la diligencia que para en el desempeño de su cargo les requiere el artículo 43.1 de la Ley de Madrid.

El artículo 95.5 de la Ley de Madrid se ajusta más al régimen estatal previsto para los administradores de las sociedades de capital, pues obliga a los administradores de las cooperativas madrileñas a solicitar la disolución judicial de la cooperativa en el plazo de dos meses contados desde que se hubiese adoptado el acuerdo contrario a la disolución o no se hubiera podido adoptar tal acuerdo. En ese caso, se cuenta el plazo bimensual desde la fecha señalada para la celebración de la asamblea, si no se hubiera constituido la misma o desde la fecha de la celebración de la asamblea, si no se hubiera podido adoptar el acuerdo. Olvida esta Ley de Madrid que puede ocurrir que no se hubiera adoptado el acuerdo porque la causa de disolución forzosa hubiese desaparecido o se hubiese enervado, en cuyo caso, los administradores no tienen ninguna obligación de solicitar la disolución judicial. Es más, la diligencia en el desempeño del cargo les exige a los administradores, en este último supuesto, no formular solicitud judicial alguna, pues tal pretensión indebida de disolución judicial podría causar perjuicios, sobre todo de pérdida de imagen comercial para la cooperativa, que estarían obligados a reparar.

Por último, el artículo 95.5 de la Ley de Madrid contiene una disposición que, en cierta medida, adelantó en su momento el artículo 262.5 LSA tras su reforma por la Ley 19/2005, de 14 de noviembre, sobre la sociedad anónima europea domiciliada en España (Chuila, 2002 y Morillas Jarillo, 2016), la cual es muy similar a la previsión italiana de los antiguos artículos 2448 y 2449 del Codice civile, hasta su reforma por el Decreto Legislativo de 10 de enero de 2003, de reforma orgánica de la disciplina de sociedades de capitales y sociedad cooperativa, en ejecución de la Ley de 3 de octubre de $2001^{11}$. Estos preceptos italianos establecían el deber legal de los administradores

11 Queda al margen la posibilidad de ejercitar contra los administradores de las Sociedades Cooperativas madrileñas la acción individual de responsabilidad prevista en el artículo 43 de la Ley de Cooperativas de Madrid, como ocurrió en la Sentencia de la Sección 19a de la Audiencia Provincial de Madrid de 7 de junio de 2004 (Ponente: Iltmo. Sr. D. Epifanio Legido López; Jur. 2004/245289). En particular sobre la exclusión del litisconsorcio pasivo necesario por causa 
de no emprender nuevas operaciones cuando las pérdidas hubiesen reducido el capital social por debajo del mínimo legal o cuando hubiese concurrido cualquier otra de las causas obligatorias de disolución contempladas en el artículo 2448 Codice civile y su consiguiente responsabilidad por el incumplimiento de tal deber, en cuyo caso sí se previene expresamente que se trata de operaciones emprendidas después de la concurrencia de la causa de disolución, con lo que se viene a responder por obligaciones sociales ex post. Pero incluso en ese caso, se admite la responsabilidad frente a los acreedores sociales anteriores, que se ven dañados por las nuevas operaciones, así como respecto de los terceros con quienes se han concertado las nuevas operaciones $^{12}$. Por su parte, la Sentencia de la Corte de Casación italiana de 12 de junio de 1997

de la solidaridad de los miembros del Consejo Rector conforme a la Ley de Cooperativas de Madrid, por ejemplo vid. la Sentencia de la Sección $10^{\mathrm{a}}$ de la Audiencia Provincial de Madrid de 17 de enero de 2018 (Ponente: Iltmo. Sr. D. José Ma . Prieto Fernández-Layos; Id Cendoj: 2807937012018100015).

12 Un buen ejemplo práctico de concepción de las "operaciones nuevas" en el Derecho italiano se puede contemplar en la Sentencia de la Corte de Casación de 28 de enero de 1995 (Rivista dei Dottori Commercialisti (1996), que las define como "todas aquellas relaciones jurídicas que, desvinculadas de la necesidad inherente a la liquidación de las actividades sociales, vienen constituidas por los administradores, con asunción de ulteriores vínculos por el ente y estando preordenadas a la consecución de nuevos beneficios", incluyendo entre tales "operaciones nuevas" la concertación de un contrato preliminar de venta de un apartamento construido por parte de la misma empresa dedicada a la construcción y venta de inmuebles, una vez que había concluido el término para el que se había constituido tal entidad, pues se destacó que tal operación no estaba impuesta por las exigencias de la liquidación social. Anteriormente, en el mismo sentido vid. la cita que hace Gambino, A., "La valutazione del rischio della responsabilità civile di amministratori e managers nelle società per azioni", Assicurazioni, marzo-junio 1994, p. 136, nota (8), de la Sentencia de la Corte de Casación 22 de noviembre de 1971. Posteriormente, vid. la Sentencia de la Corte de Casación, Italiana de 19 de septiembre de 1995 (resumida por Carbone, V. y analizada con detalle y profusión en Giurisprudenza Commerciale, septiembre-octubre 1996, pp. 662-666), donde se califica de nuevas operaciones, a estos efectos, la compra de productos farmacéuticos por una empresa, que tenía ese objeto y estaba incursa en causa de disolución, pues, se insiste, tal operación se encuentra desvinculada de las necesidades inherentes a la liquidación de la actividad social, encontrándose, por contra, incluidas en la iniciativa especulativa de la sociedad, de conformidad con la tesis difundida mayoritariamente en la doctrina italiana y ya admitida en la Sentencia de la Corte de Casación de 26 de abril de 1986.

En la doctrina italiana, puede consultarse, también, el trabajo monográfico sobre esta prohibición de emprender nuevas operaciones, que afecta no sólo al administrador sino también al liquidador (arts. 2449 y 2452 Codice civile), de Picciau, A., "Il divieto di nuove operazioni nella fase di liquidazione delle società", Studi in onore di Gastone Cottino, volumen primero, Cedam, Milán, 1997, pp. 863-890. De este trabajo interesa destacar el completo estudio que hace de la Jurisprudencia (muy estricta, como hemos visto, en cuanto a la noción de nuevas operaciones) y de la doctrina italianas (más aperturista). Concreta, por su parte, que la noción de operación no equivale a contrato, de modo que una operación puede integrarse o articularse en una multiplicidad de actos o contratos; centra la novedad en la asunción de riesgos nuevos por parte de la Sociedad, así como en que se trate de operaciones distintas y posteriores respecto de aquéllas ya emprendidas al tiempo en que concurrió la causa disolutoria, de modo que no sean un instrumento jurídico dirigido a dar comienzo a una operación económica autónoma. Así, Picciau cita como ejemplo de un contrato que no es una operación nueva a estos efectos, el 
(Le Società, 1997, p. 1397), destacó cómo la noción de "nuevas operaciones" debe desvincularse del mero dato cronológico, referente a su posterioridad respecto de la concurrencia de la causa disolutoria. Se concreta, en suma, que los administradores sólo pueden emprender operaciones dirigidas a la liquidación de la sociedad, siendo irrelevante el que la mismas, si no cumplen tal finalidad, sean o no atinentes al objeto social (Bianchi, 1998, pp. 188-189). Esto permite, en una interpretación flexible de la ley, que se emprendan esas nuevas operaciones en tanto exista la posibilidad de que la asamblea acuerde recapitalizar la sociedad o adoptar otras medidas que aseguren la continuidad de la sociedad, ello con el objeto de evitar que la brusca interrupción de actividad societaria pueda agravar la situación de la citada sociedad ${ }^{13}$. Similar a

consistente en la venta de un apartamento, por parte de una sociedad inmobiliaria, cuyo objeto fuese la adquisición de terrenos edificables para construir y vender apartamentos, puesto que entiende que sin la venta del apartamento la operación económica no estaría concluida, pues la operación especulativa se inicia con la compra de los terrenos y termina con la venta de los apartamentos edificados en ese terreno. Sí sería, por contra, en el mismo ejemplo, una operación nueva la compra de nuevos terrenos para construir otro edificio y vender los apartamentos sitos en el mismo, una vez que la sociedad ya había incurrido en causa de disolución. En fin, llama la atención Picciau acerca de que habrá que analizar caso por caso, abandonando todo apriorismo, para ver si se está o no ante una operación nueva, lo que, a nuestro juicio, es un buen ejemplo de la complejidad que presenta en este punto la normativa italiana, fuente segura de conflictos. En línea con Picciau, podemos citar también la posición de Casella, M y R. Ruozi, L'Amministratore di società, Egea, Milán, 1997, pp. 167-169, si bien estos autores van más allá y exigen, para que se desencadene responsabilidad de los administradores, algo que la Ley italiana, a nuestro entender no contempla, cual es el requisito de que la nueva operación se concluya en pérdidas para la sociedad.

13 Jaeger, P. G. y F. Denozza, Appunti di Diritto Commerciale (1997, p. 567), destacan que la voluntad del legislador fue discriminar entre actos necesarios para completar las operaciones ya en curso y el comienzo de nuevas iniciativas. Por su parte, Galgano, F., Diritto Commerciale. Le Società, Zanichelli (1998/99, pp. 368-370), admite una más amplia continuación de actividades sociales por parte de los administradores, si las mismas van encaminadas a la conservación del avviamento, en cuanto que bien social que los administradores están obligados a conservar, pudiendo incluso, a tal efecto, adquirir nuevas materias y concertar contratos laborales. Además, Galgano sostiene que estamos ante una responsabilidad frente a los acreedores sociales, no frente a la sociedad, conclusión que basa en: 1.- La responsabilidad frente a la sociedad implicaría la repetición de la acción social de responsabilidad (artículo 2392 Codice Civile). 2.- La asimilación a la responsabilidad de las asociaciones y fundaciones regulada en el artículo 29 Codice Civile. 3.- La contraposición con el artículo 2274 Codice Civile relativo a las sociedades personalistas. 4.- La simetría con el artículo 2331.2 Codice Civile, que regula la responsabilidad respecto de las operaciones emprendidas antes de la inscripción de las sociedades por acciones. Por último, Galgano se inclina por entender que esta responsabilidad de los administradores que venimos analizando excluye la responsabilidad de la sociedad por esas nuevas operaciones, de modo que no estamos ante una responsabilidad solidaria de la sociedad y sus administradores frente a los terceros acreedores. Más matizada es la tesis de Jaeger, P. G. y F. Denozza, pues sólo excluyen la responsabilidad de la sociedad frente a los acreedores sociales resultado de las nuevas operaciones cuando los mismos hubiesen actuado de mala fe, esto es, con conocimiento de la existencia de una causa de disolución y de que los actos concertados con los administradores estaban dirigidos a nuevas iniciativas y no a completar aquellas ya en curso. También Bonelli, F., "La responsabilità degli amministratori", en Trattato 
la anterior solución italiana es la contemplada en el Código de Comercio holandés (Suárez-LLanos Gómez, 1996, p. 2487), conforme a la cual se incorpora " [...] la responsabilidad por los administradores con respecto a las obligaciones que contraigan con posterioridad a la aparición de la causa de disolución para proteger, en unos casos, a los nuevos acreedores porque la medida sólo se aplica cuando la causa de disolución consista en 'la pérdida del 75 por 100 del capital social'".

Pues bien, retomando el estudio del artículo 95.5 de la Ley de Madrid ha de partirse de que el mismo, en línea con la antigua solución italiana que se acaba de sintetizar y con la vigente española del artículo 367 LSC, dice que "El incumplimiento de la obligación de convocar Asamblea General o de solicitar la disolución judicial determinará la responsabilidad solidaria de los administradores por las deudas sociales

delle Società per Azioni, dirección de G. E. Colombo y G. B. Portale, (1991, pp. 331-339), donde analiza las consecuencias de responsabilidad de los administradores que incumplen el deber de emprender nuevas operaciones de acuerdo con los artículos 2448.4 y 2449.1 Codice civile. Debe partirse de la base de que el referido artículo 2449 Codice civile, dispone: "Los administradores, cuando se haya verificado un hecho que determina la disolución de la sociedad, no pueden emprender nuevas operaciones. Contraviniendo esa prohibición, asumen responsabilidad ilimitada y solidaria por los negocios emprendidos", siendo las causas de disolución previstas en el artículo 2448 del mismo texto legal: "1) por el transcurso del término; 2) por la consecución del objeto social o por la imposibilidad sobrevenida de conseguirlo; 3) por la imposibilidad de funcionamiento o por la continuada inactividad de la asamblea; 4) por la reducción del capital social por debajo del mínimo legal, salvo en cuanto a lo dispuesto en el artículo 2447; 5) por la deliberación de la asamblea; 6) por las otras causas previstas en el acto constitutivo". Puede apreciarse cómo en esas causas de disolución falta la contemplada en el artículo 260.1.4 LSA, relativa a las pérdidas sociales que dejan reducido el patrimonio social a una cantidad inferior a la mitad del capital social.

Para la doctrina italiana, como sintetiza D'Angelo, F., "Perdita integrale del capitale sociale: conseguenze e ricostituzione", Giurisprudenza Commerciale, (1994, p. 446), el fundamento de tal prohibición de emprender nuevas operaciones se encuentra en un cambio del objeto social, por cuanto se entiende el patrimonio social vinculado a la satisfacción de los acreedores sociales y, en segundo lugar, a los singulares socios. Sin abandonar Italia, otra vez sobre la noción de nuevas operaciones, con análisis de diversos supuestos prácticos, vid. Bartalini, G., La responsabilità degli amministrattori e dei direttori generali di società per azioni, Utet, Torino, (2000, pp. 39-41) y Piselli, D., "La responsabilità degli amministratori verso la società alla vigilia della riforma", Le Società, 9 (2003, pp. 1275-1276).

Curiosamente, con cita de Bonelli, en nuestra doctrina Prendes CarriL, P., Pérdidas y Responsabilidad Civil de los Administradores en las Sociedades de Capital, Ilustre Colegio de Abogados de Gijón (1996, p. 77), proyecta la anterior doctrina italiana sobre la completamente distinta dicción de nuestro originario artículo 262.5 LSA, razón por la cual estimamos desacertada esta opinión doctrinal, que pretendía, en aquellos momentos, reducir el ámbito objetivo de la responsabilidad que analizamos a las deudas sociales contraídas con posterioridad al incumplimiento de sus obligaciones por los administradores. Sorprendentemente, el mismo autor, sostiene que en casos de insolvencia de la Sociedad Anónima sus administradores responderían por todas las deudas sociales, sin aportar otro criterio que el de no perjudicar a los primeros acreedores, criterio que opera también aun cuando la Sociedad Anónima fuese solvente, pues como bien sabemos la solvencia inicial no quiere decir que al final todos los acreedores sean efectivamente satisfechos. 
nacidas a partir del momento en que expira el plazo para solicitar la disolución judicial". Ahora bien, dicho precepto carece, a nuestro juicio, de justificación lógica, puesto que, si los administradores ya incumplieron la obligación de convocar la Asamblea General de disolución, no hay razón para restringir el ámbito de su responsabilidad a las obligaciones contraídas tras haber incumplido también su obligación de instar la disolución judicial. El precepto tendría lógica interna si hubiera hecho responder a los administradores de las deudas posteriores al incumplimiento de su primera obligación, que era la de convocar, no la de solicitar la disolución judicial, interpretación que ya se ha visto acogida en la jurisprudencia menor ${ }^{14}$.

También similar a la vieja solución italiana es la contemplada en el artículo 92.5 de la primitiva Ley de Castilla-La Mancha -idéntico el artículo 112.5 de la vigente Ley de 2010-, cuando dice que "El incumplimiento de la obligación de convocar Asamblea General o de solicitar la disolución judicial determinará la responsabilidad solidaria de los miembros del Consejo por las deudas sociales nacidas a partir del momento en que concurra efectivamente la causa de disolución". Previsión que es más próxima a la italiana que la legislación madrileña, y, además, más acertada porque toma como dies a quo de las deudas de las que se hace responder a los administradores - esto es, del ámbito objetivo de esta responsabilidad- el de la concurrencia de la causa de

14 Así, Sentencia de la Sección $28^{a}$ de la Audiencia Provincial de Madrid de 27 de enero de 2012 (Ponente: Iltmo. Sr. D. Pedro Ma. Gómez Sánchez; Id Cendoj: 28079370282012100020): "determinar que a finales de enero de 2006 expiraba el plazo de 2 meses con el que contaban los demandados, por imperativo del Art. 95-5 de la misma ley, para promover la disolución de la cooperativa al efecto convocando asamblea general al efecto, por lo que, no resultando controvertido que nada hicieron al respecto, quedaron sometidos, automáticamente, al régimen de responsabilidad solidaria que dicho precepto establece [...] Por lo tanto, habiéndose situado temporalmente ese momento en el final del mes de enero de 2006, el régimen de responsabilidad que dicho precepto legal establece nunca podría alcanzar a los demandados respecto del nominal y gastos de devolución ( $9.108,99$ euros + 123,53 euros) de un pagaré que resultó incorriente y que vencía el 10 de octubre de 2005, época ésta en la que, tal y como nos expone la propia apelante en los dos primeros párrafos de la página 8 de su recurso, no concurrían aún, pese a la proximidad temporal, las causas de disolución invocadas en la demanda con mayor o menor precisión. En relación con los intereses, partiendo de los criterios de cálculo -cuya corrección no ha resultado controvertida en el presente proceso- contenidos en el Documento 3 de la demanda (folio 141), del total de 1.458,19 euros que dicho documento refleja habrá que deducir la suma de 92,83 euros que es, aplicando una sencilla regla de equivalencia, la cantidad devengada durante los meses de diciembre de 2005 y enero de 2006 en que aún no había expirado el plazo legalmente establecido para la adopción por parte de los demandados de las iniciativas disolutorias correspondientes, todo lo cual nos arroja por este concepto una deuda imputable a los demandados, en cuanto que nacida con posterioridad al 31 de enero de 2006, de 1.365, 36 euros. Por otro lado, del Documento 4 de la demanda (folio 142) se infiere con claridad que el crédito por razón de costas del proceso previo mantenido contra la cooperativa $(2.561,11$ euros) nació con holgada posterioridad a la fecha de referencia, con lo que resulta también plenamente imputable a los codemandados". 
disolución forzosa, que es justamente el desencadenante de la necesidad de actuación de los administradores.

Con el paso de los años es preciso advertir que las previsiones de la citada ley de Castilla-La Mancha han coincidido con el ámbito objetivo de la responsabilidad de los administradores de las S.A. (artículo 262.5 LSA) y S.R.L. (artículo 105.4 LSRL), tras su reforma, antes mencionada, del año 2005 y antes de su "recodificación". También ahora los administradores de las S.A. y de las S.R.L. que incumplen el deber de convocar junta general de accionistas o de socios de disolución o, en su caso, de instar la disolución judicial, amén de solicitar la declaración de concurso necesario de la sociedad insolvente, responden sólo de las deudas societarias posteriores al acaecimiento de la causa legal de disolución o, como dice la citada Ley de Castilla-La Mancha, "nacidas a partir del momento en que concurra efectivamente la causa de disolución".

En línea con las previsiones legales mencionadas, aunque con algunas importantes matizaciones, está el artículo 97 de la Ley de Cooperativas de Murcia. Su redacción no fue, como se va a analizar, un dechado de perfección técnica. Así, destaca el que mientras el artículo 97.3 de dicha Ley de Cooperativas de Murcia dice que el Consejo Rector "podrá" instar la disolución de la sociedad o la declaración de concurso de la sociedad insolvente, a renglón seguido, en el artículo 97.4, contempla una sanción para los miembros del Consejo Rector que no soliciten la disolución judicial de las cooperativas incursas en determinadas causas de disolución forzosa o la declaración en concurso de las insolventes, buena muestra de que, en realidad, el antes referido "podrá" ha de entenderse como "deberá", no siendo además las causas de disolución previstas en dicha ley murciana totalmente coincidentes con las previstas en la LSC ${ }^{15}$.

Por otro lado, la opción murciana introduce un matiz más en el régimen legislativo autonómico a la hora de delimitar el ámbito objetivo de la responsabilidad sanción de los miembros del Consejo Rector por no haberse convocado la Asamblea General de disolución, no haber instado la disolución judicial o no haber solicitado la declaración de concurso. Pues conforme al señalado artículo 97.4 de la Ley de Cooperativas de Murcia, la misma alcanza a "todas las deudas sociales generadas un mes después de que se constatara la causa que justifica la disolución o declaración de concurso"16.

15 Como ya advirtió la Sentencia de la Sección $4^{\text {a }}$ de la Audiencia Provincial de Murcia de 19 de octubre de 2017 (Ponente: Iltmo. Sr. D. Rafael Fuentes Devesa; Id Cendoj: 30030370042017100673)

16 Aplicación práctica de este precepto se encuentra en la Sentencia del Juzgado de lo Mercantil $\mathrm{n}^{\circ} 1$ de Murcia de 15 de julio de 2014 (Iltmo. Sr. D. Francisco Cano Rico; Id Cendoj: 30030470012014100133): "Considerando, pues, que la sociedad demandada estaba incursa en causa de disolución en el ejercicio 2009, y que las obligaciones a las que se comprometieron vencían, último pagaré, el 25 de septiembre de 2010, debe declararse la responsabilidad solidaria de los miembros del Consejo Rector por todas las deudas sociales generadas un mes 
La novedad estriba en que aquí se concede un plazo de cortesía de un mes, lo cual coincide con el que el artículo 97.1 de la misma ley prevé para que el Consejo Rector cumpla con su obligación de convocar Asamblea General de disolución. No compartimos el que se conceda este plazo de stand by, pues permite que durante ese periodo se contraigan deudas sociales de las que no responderán los miembros del Consejo Rector, pese a que luego incumplan sus obligaciones en un momento en el que ya conocían la existencia de causa de disolución forzosa o de declaración de concurso. Se introduce, pues, un casuismo cuya justificación no es válida y, además, a nuestro juicio, contradice la propia finalidad de la norma, evitar que se contraigan deudas por el Consejo de Rector de Cooperativas en causa de disolución forzosa o en insolvencia ${ }^{17}$.

Por último, el régimen andaluz, también obliga a que el órgano de administración convoque a la Asamblea General para acordar la disolución dentro del plazo de treinta días (artículo 67.2 del Reglamento de 2014), siempre que concurran alguna de las siguientes causas de disolución del artículo 79 de la Ley 14/2011: a) el cumplimiento del plazo fijado en los estatutos sociales; b) la conclusión de su objeto o

después de que se constatara la causa que justifica la disolución entre las que se encuentran las deudas aquí reclamadas, por lo que la demanda debe ser íntegramente estimada. Y a lo anterior no obsta la tardía solicitud de concurso de la cooperativa pues si debía haberse solicitado la disolución en el ejercicio 2009, la solicitud y simultaneo archivo del concurso en el año 2012 no exime de responsabilidad a los miembros del Consejo Rector", y en la Sentencia de la Sección $4^{a}$ de la Audiencia Provincial de Murcia de 19 de octubre de 2017 (Ponente: Iltmo. Sr. D. Rafael Fuentes Devesa; Id Cendoj: 30030370042017100673 ): "Salvo que se trate de sentencias constitutivas, no podemos aceptar como data relevante la de la sentencia cuando la deuda deriva de relaciones contractuales. En ese caso la deuda nace del acuerdo de voluntades, como dijimos en nuestra sentencia de 5 de noviembre de 2015 y 19 de mayo de 2016, en sintonía con la SAP de Alicante, de 11 de noviembre de 2009, SAP de Pontevedra, de 3 de mayo de 2011 , SAP Castellón, de 1 de julio de 2008 y SAP de Zaragoza de 13 de marzo de 2013 , y así lo apunta la STS de 8 de octubre de 2014 , en el caso de una obligación sujeta a condición suspensiva. Y ello al margen del momento de la determinación judicial de su existencia en ulterior sentencia, pues i) la sentencia no tiene eficacia constitutiva de la obligación, sino declarativa, y ii) la seguridad jurídica - art 9CE - impide tomar como referencia la fecha de sentencia, pues se dejaría en manos de la parte acreedora la delimitación del ámbito de aplicación del régimen de responsabilidad solidaria consagrado en la legislación societaria y de cooperativas, pues le bastaría con demandar a la sociedad tras la concurrencia de la causa de disolución para extender el ámbito de la responsabilidad de los administradores".

17 orprendentemente para nosotros, la Sentencia de la Sección $4^{\mathrm{a}}$ de la Audiencia Provincial de Murcia de 14 de octubre de 2010 (Ponente: Iltmo. Sr. D. Juan Martínez Pérez; Id Cendoj: 30030370042010100511 ), acude al artículo 262.5 LSA -en esa línea también aplicó, incorrectamente a nuestro juicio, el artículo 367 LSC a una sociedad cooperativa murciana, la Sentencia del Juzgado de lo Mercantil no 1 de Murcia de 15 de marzo de 2016 (Iltma. Sra. $D^{a}$. M ${ }^{a}$. Dolores de las Heras García; Id Cendoj: 3003047002016100050)- a pesar de citar el artículo 97 de la Ley 8/2006, de 16 de noviembre, de Sociedades Cooperativas de la Región de Murcia, en tanto que la Sentencia del Juzgado de lo Mercantil $\mathrm{n}^{\circ} 2$ de Murcia de 2 de marzo de 2016 (lltmo. Sr. D. Francisco Cano Marco; Id Cendoj: 3003047002016100032 ) ya acudió directamente a la aplicación del precepto específico autonómico murciano en materia de cooperativas ya referido. 
la imposibilidad de realizar la actividad cooperativizada; c) la ausencia de actividad cooperativizada principal o su realización instrumental o accesoria, en ambos casos, durante dos años consecutivos [...]; e) la reducción del número de socios o socias por debajo del mínimo legalmente necesario para constituir la sociedad cooperativa por un periodo superior a doce meses; f) la reducción del patrimonio contable hasta quedar por debajo del capital social estatutario, a no ser que, en el plazo de doce meses, se proceda a su reajuste, y siempre que no deba solicitarse la declaración de concurso [...]; h) la inactividad de alguno de los órganos sociales necesarios durante dos años consecutivos; j) cualquier otra causa establecida en la ley o en los estatutos. Y además el órgano de administración está obligado a instar la disolución judicial si: a) la Asamblea General no fuese convocada; b) la Asamblea General no se reuniese en el plazo fijado en los estatutos; c) la Asamblea General no pudiese adoptar el acuerdo de disolución; d) la Asamblea General adoptase un acuerdo contrario a declarar la disolución (artículo 67.3 del Reglamento de 2014, en desarrollo del artículo 79.3 de la Ley 14/2011, de Sociedades Cooperativas Andaluzas). La laguna que presenta la legislación andaluza en este último punto es que no se fija un plazo para instar la disolución judicial, lo que puede dejar sin contenido, en tal caso, la consecuencia que seguidamente se analizará, a menos que se interprete que, como no hay previsión legal de plazo, la disolución judicial ha de solicitarse de forma inmediata, una vez concurran los presupuestos para la misma.

El artículo 79.3.2 de la Ley 14/2011 contempla que el incumplimiento del deber de convocar la Asamblea General para acordar la disolución, del deber de solicitar la disolución judicial o del deber de solicitar la declaración de concurso determinará la responsabilidad solidaria de los miembros del órgano de administración por todas las deudas sociales generadas a partir del mes siguiente a que se constate la causa que justifica la disolución o declaración de concurso.

Estamos pues ante un nuevo régimen de responsabilidad por no disolución que se concreta en limitar su ámbito subjetivo a dudas sociales posteriores no a la causa de disolución sino al transcurso de un mes desde la constatación, hay que entender que, con la diligencia debida, de la concurrencia de esa causa. Se contempla así, de nuevo, sin causa a nuestro juicio, un plazo de un mes en el que los acreedores sociales quedarán desprotegidos.

Por otro lado, es de advertir que, en cuanto a la responsabilidad por no solicitar la declaración de concurso, entendemos que de condenarse a los administradores de una cooperativa andaluza a la cobertura del déficit concursal conforme al artículo 172 bis LC quedará la normativa autonómica embebida en este último supuesto. 
3. La atribución de deberes a los administradores sin fijación de un régimen especial de responsabilidad -es el caso del artículo 81.2 de la Ley de Cooperativas de la Comunidad Valencia y del artículo 88.2 y 3 de la Ley de Cooperativas del País Vasco-.

Este sistema consiste en enumerar una serie de causas de disolución forzosa de la sociedad cooperativa, cuya concurrencia obliga a que los administradores de la misma deban:

a) Convocar la Asamblea General en el plazo de dos meses a contar desde que tengan conocimiento de la causa de disolución forzosa.

En este punto debemos mostrarnos críticos, por su falta de claridad, con el antes mencionado artículo 81.2 de la Ley Valenciana porque comienza con un enigmático "cuando proceda", que, a nuestro juicio, debe entenderse que se refiere a "cuando concurra alguna de las causas de disolución forzosa". Seguidamente fija como dies a quo para el cómputo de los dos meses que los administradores tienen para convocar, el momento en "que se aprecie la existencia de causa de disolución", debiendo entenderse que, en realidad, lo que se quiere decir es el momento en que los administradores, ejerciendo su cargo con la diligencia que les exige el artículo 47 de dicha Ley Valenciana, debieron conocer algo tan importante en la vida de la sociedad como es la concurrencia de una causa de disolución forzosa.

b) Para el caso de que la Asamblea no se convocase o no se reuniese en el momento para el que hubiese sido convocada, deberán solicitar la disolución judicial de la cooperativa.

Nuevamente debemos criticar la falta de claridad de la normativa autonómica en este punto. Así, el artículo 81.2 de la Ley Valenciana no tiene en cuenta la posibilidad de que se adopte un acuerdo contrario a la disolución porque dicha causa ya hubiese desaparecido o se hubiese adoptado un acuerdo de enervación de la misma. Por otro lado, dicha Ley Valenciana, lo mismo que la antes citada Ley del País Vasco, no concreta el plazo que tienen los administradores para solicitar en tales supuestos la disolución judicial de la cooperativa.

c) Pero sin que el incumplimiento de los citados deberes acarree un régimen especial de responsabilidad. De este modo, la responsabilidad de 
los administradores de las sociedades cooperativas que incumplan los referidos deberes de convocar Asamblea General de disolución o instar la disolución judicial de la cooperativa será la general establecida en los preceptos que regulan la misma en sus correspondientes leyes, como una clásica responsabilidad que requiere culpa, daño y relación de causalidad (artículo 47 de la Ley Valenciana, por ejemplo).

4. Atribución de deberes al órgano de administración, sin referencia individualizada a sus miembros y sin previsión de un régimen de responsabilidad especial a los mismos (artículo 96.2 y 3 de la Ley 1/2003, de 20 de marzo, de Cooperativas de las Illes Balears; artículo 111.2 y 3 de la Ley 2/1999, de 31 de marzo, de Sociedades Cooperativas Andaluzas, hoy derogada; en parte, los artículos 90.2 de la Ley 4/2002, de 11 de abril, de Cooperativas de la Comunidad Autónoma de Castilla y León ${ }^{18}, 94.2$ de la Ley 4/2001, de 2 de julio, de Cooperativas de La Rioja y 97.2 de la Ley 2/1998, de 26 de marzo, de normas reguladoras de las Sociedades Cooperativas de Extremadura, ya que no obligan en ningún caso a que el Consejo Rector solicite la disolución judicial de la Cooperativa que administra y el artículo 87.2 de la Ley 5/1998, de 18 de diciembre, de normas reguladoras de las Cooperativas de

18 Sobre la no aplicación a las cooperativas de Castilla y León de la responsabilidad del artículo 367 LSC, por falta de previsión legal expresa en su Ley autonómica, vid. las Sentencias de la Sección $1^{\text {a }}$ de la Audiencia Provincial de León de 12 de julio de 2012 (Ponente: Iltmo. Sr. D. Ricardo Rodríguez López; Id Cendoj: 24089370012012100322 ) y de la Sección $1^{\text {a }}$ de la Audiencia Provincial de Salamanca de 15 de enero de 2013 (Ponente: Iltmo. Sr. D. José Ramón González Clavijo; Id Cendoj: 37274370012013100006$)$, confirmada por la Sentencia de la Sala $1^{\text {a }}$ del Tribunal Supremo de 10 de marzo de 2015 (Ponente: Excmo. Sr. D. Sebastián Sastre Papiol; Id Cendoj: 28079110012015100124$)$-reiterada esta última en las Sentencias de la Sección $3^{\text {a }}$ de la Audiencia Provincial de Burgos de 18 de noviembre de 2015 (Ponente: Iltma. Sra. Da. Ma: Esther Villimar San Salvador; Id Cendoj: 090537003201510023$)$, del Juzgado de lo Mercantil $n^{\circ} 1$ de Valladolid de 29 de octubre de 2015 (Iltmo. Sr. D. Javier Escarda de la Justicia; Id Cendoj: 47186470012015100140) y de la Sección $3^{\text {a }}$ de la Audiencia Provincial de Burgos de 13 de febrero de 2017 (Ponente: Iltmo. Sr. D. Ildefonso Barcalá Fernández de Palencia, Id Cendoj: 09059370032017100050$)-$, en la que también se destaca que no cabe esta modalidad de responsabilidad en aplicación de la Ley nacional de cooperativas; cfr. las Sentencias de la Sección $3^{\text {a }}$ de la Audiencia Provincial de Burgos de 11 de enero de 2012 (Ponente: Iltmo. Sr. D. Juan Francisco Sancho Fraile; Id Cendoj: 09059370032012100006) y de la Sección $1^{\text {a }}$ de la Audiencia Provincial de Segovia de 9 de noviembre de 2015 (Ponente: Iltmo. Sr. D. Ignacio Pando Echevarría; Id Cendoj: 40194370012015100352) y de 22 de marzo de 2016 (Ponente: Iltmo. Sr. D. Ignacio Pando Echevarría; Id Cendoj: 40194370012016100145) -en particular esta última, haciendo aplicación de la remisión defectiva del artículo 51 de la Ley de Cooperativas de Castilla y León a la LSA, se remite a la aplicación del artículo 367 LSC-. 
Galicia, que se limita a facultar, no obligar, al Consejo Rector para solicitar la disolución judicial19).

Por su parte, el artículo 96.2 de la Ley de Illes Balears, habla de que cuando concurra alguna de las causas de disolución forzosa que sí concreta por referencia al artículo 95, "deberá convocar a la Asamblea General", sin concretar quién deberá convocar. Hay que integrar ese precepto con el resto de la ley, y, en particular, con su artículo 40.1, para entender que el deber de convocar se proyecta sobre el Consejo Rector y no sobre los administradores individualmente considerados. De hecho, tal es la previsión expresa que sí contienen los artículos 92.2 de la primitiva Ley de Castilla-La Mancha -artículo 112.2 de la vigente Ley de 2010-, 90.2 de la Ley de Castilla y León, 94.2 de la Ley de La Rioja, 111.2 de la Ley de Andalucía hoy derogada y 97.2 de la Ley de Extremadura-.

Por otro lado, el citado artículo 96.2 de la Ley de Illes Balears, al igual que los mencionados artículos 96.2 de la primitiva Ley de Castilla-La Mancha -artículo 112.2 de la vigente Ley de 2010-, 111.2 de la Ley de Andalucía hoy derogada y 97.2 de la Ley de Extremadura, se aparta del plazo habitual bimestral para convocar y fija uno más pequeño, de sólo treinta días - un mes en los artículos 90.2 de la Ley de Castilla y León, 94.2 de la Ley de La Rioja y 87.2 de la Ley de Galicia-, que deben computarse sólo los hábiles conforme a la disposición adicional primera de la primitiva Ley de Castilla-La Mancha y a la disposición adicional segunda de la Ley de Andalucía hoy derogada, pero que respecto de la Ley de Extremadura al ser un plazo civil y no contener esta última régimen especial al respecto habrá que entender que comprenderá días hábiles e inhábiles (artículo $5.1 \mathrm{CC}$ ), todo ello sin concretar en ninguno de los casos cuál es el dies a quo de tal plazo, lo mismo que ocurre en los meritados artículos 94.2 de la Ley de La Rioja, 111.2 de la Ley de Andalucía, 97.2 de la Ley de Extremadura y 87.2 de la Ley de Galicia. Sí concreta, aunque sin acierto por no tener en cuenta el momento en que el Consejo Rector actuando con diligencia debió conocer, ese momento el artículo 96.2 de la primitiva Ley de Castilla-La Mancha -artículo 112.2 de la vigente Ley de 2010- "desde el momento en que concurran las causas señaladas en el apartado anterior" esto es, las causas de disolución forzosa. Tampoco es afortunada la referencia del artículo 90.4 de la Ley de Castilla-León al dies a quo consistente en

19 En particular, sobre la diferencia entre el régimen de responsabilidad de los miembros del Consejo Rector de las sociedades cooperativas gallegas y el régimen de los administradores de las sociedades de capital, especialmente sobre la ausencia de preceptos autonómicos gallegos cooperativos parangonables a los entonces artículos 262.5 LSA y 105.5 LSRL, vid. la Sentencia de la Sección $1^{\text {a }}$ de la Audiencia Provincial de Pontevedra de 15 de septiembre de 2011 (Ponente: Iltma. Sra. Da. Ma. Begoña Rodríguez González; Jur. 2011/347996). 
"desde que se haya constatado la existencia de causa de disolución", pues de nuevo deja sin decir que tal fecha de constatación debió ser aquélla resultante del ejercicio diligente de su cargo por parte de los administradores integrantes del Consejo Rector de la Cooperativa.

Los artículos 96.3 de la Ley de Illes Balears y 111.3 de la Ley de Andalucía, hoy derogada, obligan a que el Consejo Rector solicite la disolución judicial, pero no concretan ni en qué plazo ni qué consecuencias se derivan del hecho de que el Consejo Rector no solicite la disolución judicial de la cooperativa. Tratándose una obligación sin plazo, el incumplimiento de tal deber no puede acarrear punición alguna y cualquier responsabilidad que se pretendiese imputar a los miembros del Consejo Rector debe venir por la vía de los artículos 63 y 64 de la Ley de Illes Balears, y 72 y 73 de la Ley de Andalucía hoy derogada, que regulan en general la responsabilidad de los miembros del Consejo Rector, de los Interventores y del Director ${ }^{20}$.

Por su parte, el artículo 92.4 de la Ley de Castilla-La Macha sí que concreta un plazo para que el Consejo Rector solicite la disolución judicial a que viene obligado, el clásico bimestral contado desde la fecha prevista para la celebración de la Asamblea General de disolución cuando la misma no se hubiese llegado a constituir o desde el día de la Asamblea que hubiese adoptado acuerdo contrario a la disolución o no hubiese adoptado el acuerdo de disolución, olvidando, eso sí, una vez más, la posibilidad de que la adopción de acuerdo contrario a la disolución o de no adopción de acuerdo de disolución pueden estar perfectamente fundados en la desaparición de la causa de disolución o en la adopción de un acuerdo de enervación de la misma.

5. Ausencia total de previsión expresa alguna sobre específicos deberes de los administradores ni del Consejo Rector en estos supuestos -artículo 86 de la Ley 18/2002, de 5 de julio, de Cooperativas de Cataluña y actual

20 Aplicación práctica de la remisión al régimen general de responsabilidad de los artículos 133 y 135 LSA por el artículo 72.3 de la Ley 2/1999, de 31 de marzo, de Sociedades Cooperativas Andaluzas, puede consultarse en las Sentencias de la Sección $3^{\text {a }}$ de la Audiencia Provincial de Córdoba de 18 de enero de 2008 (Ponente: Iltmo. Sr. D. Pedro José Vela Torres; Id Cendoj: 14021370032008100007), de la Sección $5^{\text {a }}$ de la Audiencia Provincial de Sevilla de 21 de julio de 2008 (Ponente: Iltmo. Sr. D. Juan Márquez Romero; Id Cendoj: 41091370052008100373), de la Sección $1^{\text {a }}$ de la Audiencia Provincial de Jaén de 30 de junio de 2010 (Ponente: Iltma. Sra. Da. Esperanza Pérez Espino; Jur. 2010/370377), de la Sección $5^{\text {a }}$ de la Audiencia Provincial de Sevilla de 12 de diciembre de 2013 (Ponente: Iltmo. Sr. D. Juan Márquez Romero; Id Cendoj: 41091370052013100565), de la Sección 6a de la Audiencia Provincial de Málaga de 18 de junio de 2014 (Ponente: Iltma. Sra. $D^{a}$. Nuria Auxiliadora Orellana Cano; Id Cendoj: 29067370062014100441 ) y de 19 de febrero de 2014 (Ponente: Iltmo. Sr. D. José Javier Díez Núñez; Id Cendoj: 29067370062014100133) y de la Sección 5a de la Audiencia Provincial de Sevilla de 29 de septiembre de 2014 (Ponente: Iltmo. Sr. D. Juan Márquez Romero; Id Cendoj: 41091370052014100536). 
artículo 102 de la Ley 12/2015, de 9 de julio, de Cooperativas de Cataluña, artículo 67 de la Ley 9/1998, de 22 de diciembre, de normas reguladoras de las cooperativas de Aragón, actualmente artículo 67 del Texto Refundido de la Ley de Cooperativas de Aragón aprobado por Decreto Legislativo 2/2014, de 29 de agosto, y artículo 61 de la Ley Foral 14/2006, de 11 de diciembre, que regula las cooperativas de Navarra-.

En este caso, y lo mismo que en los supuestos en que se establece un deber de actuación de los administradores de las sociedades cooperativas en causa de disolución forzosa sin fijación de un régimen especial de responsabilidad, debe entenderse que el hecho de que los administradores no convoquen Asamblea General de disolución ni insten la disolución judicial de la cooperativa no genera responsabilidad per $s^{21}$.

Ello no se debe confundir con la posibilidad de que sí se incurra en responsabilidad cuando los administradores cesasen de facto la actividad cooperativa y dejasen a la sociedad cooperativa inactiva, desentendiéndose de ella y de sus acreedores. Si bien tal responsabilidad será una responsabilidad ordinaria por daños que exige la culpa, el daño y la relación de causalidad en el marco del ejercicio de una acción individual de responsabilidad de administradores, que, por supuesto, nada tiene que ver con la responsabilidad-sanción del artículo 262.5 LSA, hoy artículo 367 LSC 22.

21 En Aragón, en la práctica, por ejemplo, en tal sentido vid. la Sentencia de la Sección $5^{\text {a }}$ de la Audiencia Provincial de Zaragoza de 30 de abril de 2012 (Ponente: Iltmo. Sr. D. Javier Seoane Prado; Jur. 2012/182123) y la Sentencia del Juzgado de lo Mercantil n 2 de Zaragoza de 11 de junio de 2015 (Iltma. Sra. Da. María Sáenz Martínez; Id Cendoj: 50297470022015100196), entendiendo además esta última respecto del artículo 43 de la Ley de 9/1998, de 27 de diciembre, de Cooperativas de Aragón, que "la remisión del artículo 43 de la Ley nacional no comprende la responsabilidad como sanción. Atendiendo a la distinta naturaleza y contenido de la responsabilidad como sanción y de la responsabilidad por daños, y a la vista del tenor literal de artículo 43 en la que se determina "La responsabilidad de los Consejeros e interventores por daños causados", y en contraposición de la responsabilidad prevista 367 del TRLSC que hace responsables a los administradores por las deudas sociales como consecuencia del incumplimiento de una concreta obligación legal, y no por los daños causados. Asimismo, la normativa del TRLSC (artículo 367) es de carácter sancionador, se habla de pena o sanción civil, y las normas sancionadoras deben interpretarse con carácter restrictivo, no extendiendo su aplicación a supuestos que no hayan sido previstos expresamente por el legislador".

22 Así, entre otras, Sentencias de la Sección 15 a de la Audiencia Provincial de Barcelona de 8 de octubre de 2002 (Ponente: Iltmo. Sr. D. Juan Francisco Garnica Martín; Jur. 2004/16357) y de 24 de enero de 2005 (Ponente: Iltmo. Sr. D. Luis Garrido Espá; Jur. 2005/54742) y de la Sección $1^{\text {a }}$ de la Audiencia Provincial de Girona de 28 de junio de 2004 (Ponente: Iltmo. Sr. D. Fernando Ferrero Hidalgo; AC 2004/1462) -aplicando todas ellas la Ley de Cooperativas de Cataluña-, de la Sección $3^{a}$ de la Audiencia Provincial de Granada de 11 de febrero de 2004 (Ponente: Iltmo. Sr. D. Klaus Jochen Albiez Dorhmann; Jur. 107232), de la Sección $1^{\text {a }}$ de la Audiencia Provincial de Zamora de 28 de julio de 2005 (Ponente: Iltmo. Sr. D. Pedro Jesús García Garzón; Jur. 2005/206782), de la Sección 9a de la Audiencia Provincial de Valencia de 19 de septiembre de 2005 (Ponente: Ilma. Sra. Da . Rosa Ma . Andrés Cuenca; Jur. 2005/275154) -aplicando la 


\section{El sistema estatal}

En la vigente Ley estatal de Cooperativas (Ley 27/99, de 16 de julio) existe un problema diferente a la hora de analizar la situación de los administradores de las sociedades cooperativas incursas en causa de disolución forzosa.

El artículo 43 de la Ley estatal de Cooperativas contiene el régimen general de responsabilidad de los consejeros e interventores de las cooperativas y les somete al régimen de responsabilidad de los administradores de las S.A., con la única salvedad de que los interventores no tendrán responsabilidad solidaria.

Ley de Cooperativas de Valencia-, de la Sección $3^{\text {a }}$ de la Audiencia Provincial de Badajoz de 11 de febrero de 2005 (Ponente: Iltma. Sra. Da. Marian Muñoz Acero; Jur. 2005/75339) y de la

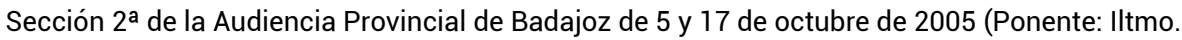
Sr. D. Carlos Paumard Collado; AC 2005/2007 y Ponente: Iltmo. Sr. D. Carlos Jesús Carapeto y Márquez de Prado; Jur. 2005/260131, respectivamente) -aplicando la Ley de Cooperativas de Extremadura- y de la Sección $5^{a}$ de la Audiencia Provincial de Sevilla de 19 de febrero de 2015 (Ponenete: Iltmo. Sr. D. Fernando Sanz Tayalero; Id Cendoj: 41091370052015100062) -aplicando la Ley 1/1999 de 31 de marzo de Sociedades Cooperativas Andaluzas-.

Erróneamente en contra, vid. las Sentencias de la Sección $2^{\mathrm{a}}$ de la Audiencia Provincial de Guipúzcoa de 24 de septiembre de 2004 (Ponente: Iltmo. Sr. D. Augusto Maeso Ventureira; Jur. 2004/308750) y de la Sección $1^{\text {a }}$ de la Audiencia Provincial de Vizcaya de 18 de febrero de 2005 (Ponente: Iltmo. Sr. D. Fernando Valdés-Solis Cecchini; AC 2005/612) -esta última referida críticamente por Vázquez Pena, M. J., "La aplicación del apartado quinto del artículo 262 del Texto refundido de la Ley de Sociedades Anónimas a las Sociedades Cooperativas", CIRIEC Revista Jurídica de Economía Social y Cooperativa, 18 (2007, pp. 39-40 y 47-49)-, en las que, aplicando la Ley de Cooperativas del País Vasco de 1993, que tampoco contiene un régimen de responsabilidad asimilable al artículo 262.5 LSA, proceden a hacer lo que la última de ellas de forma más explícita denomina "aplicación abierta de dicho precepto"; posteriormente vuelve a entender la Sentencia de la Sección $1^{\text {a }}$ de la Audiencia Provincial de Vitoria de 13 de marzo de 2014 (Ponente: Iltmo. Sr. D. Edmundo Rodríguez Achúetgui; Id Cendoj: 01059370012014100043), que la legislación autonómica vasca remite al en su momento vigente artículo 262.5 LSA, conclusión que, sin argumenjto y respecto del artículo $367 \mathrm{LSC}$, mantuvo años después la Sentencia del Juzgado de lo Mercantil $\mathrm{n}^{\circ} 1$ de San Sebastián de 25 de enero de 2017 (Iltma. Sra. $\mathrm{D}^{\mathrm{a}}$. $\mathrm{M}^{\mathrm{a}}$. Francisca Fustero Aznar; Id Cendoj: 20069470012017100027 ), criterio que corrige la Sentencia del Juzgado de lo Mercantil $n^{\circ}$ 2 de Bilbao de 25 de noviembre de 2015 (Iltma. Sra. $D^{\mathrm{a}}$. $\mathrm{M}^{\mathrm{a}}$. Henar Torres Martín; Id Cendoj: 48020470022015100266) -en el mismo sentido Sentencias del Juzgado de lo Mercantil de Vitoria de 16 de enero de 2017 (Iltma. Sra. $D^{a}$. M ${ }^{a}$. Teresa Trinidad Santos; Id Cendoj: 01059420072017100014 ) y de 29 de septiembre de 2017 (Iltmo. Sr. D. Iñigo Elizburu Aguirre; Id Cendoj: 01059370012017100377$)--$, rotunda esta última en que "ni en el art. 87 de la Ley de Cooperativas de Euskadi ni menos aún en los estatutos de la propia cooperativa (art. 4) se contempla como causa de disolución la establecida en el art. $367 \mathrm{LSC}$ por lo que no es posible una aplicación extensiva de la acción de responsabilidad social a este supuesto porque la propia normativa aplicable no la contempla".

En la doctrina, Morillas Jarillo y Feliú Rey, pero considerando que se trataría de una acción ordinaria de responsabilidad extracontractual del artículo $1902 \mathrm{CC}$, pues son contrarios a entender que el artículo 43 de la Ley estatal de Cooperativas remita a la acción individual de responsabilidad de los administradores del artículo 135 LSA. 
Más adelante, cuando se regula la disolución de las sociedades cooperativas, la referida ley estatal, en su artículo 70, no contempla el mismo régimen de disolución forzosa que el artículo 262 LSA, hoy artículos 365 a 367 TRLSC. Concretamente, aunque el artículo 70.3 de la Ley 27/99 obliga al Consejo Rector a convocar, en el plazo de un mes a contar desde la constatación -hay que suponer que diligente, por remisión al artículo 127 LSA, hoy artículos 225 y 226 TRLSC, en virtud de lo previsto en el 43 de la Ley estatal de Cooperativas - de las causas de disolución forzosa, la Asamblea General de disolución, no regula qué consecuencias, ni qué sanciones, derivan del incumplimiento de tal deber - nótese que la Ley estatal de Cooperativas no obliga, en ningún caso, a que el Consejo Rector ni los administradores individualmente considerados hayan de solicitar la disolución judicial de la Cooperativa ${ }^{23}-$.

Para integrar el vacío legal referenciado cabe seguir dos interpretaciones:

1. Una primera interpretación, la cual consiste en entender que el legislador estatal pudo considerar que establecer una regulación específica de las consecuencias del incumplimiento del antes referido deber del Consejo Rector sería redundante. Al haberse remitido en el artículo 43 de la Ley 27/99 al régimen de responsabilidad de los administradores de las S.A., en dicha remisión ya estaba comprendida la responsabilidad sanción de los administradores prevista en el artículo 262.5 LSA, hoy artículo 367 TRSLC. Se trataría de la ecuación responsabilidad de los administradores de la Cooperativa = responsabilidad de los administradores de la S.A. = responsabilidad sanción por no disolución forzosa.

Esta primera interpretación la rechazamos, porque el artículo 43 de la Ley estatal de Cooperativas dice que la responsabilidad de los administradores de las cooperativas que se rige por lo dispuesto para los administradores de las S.A. es literalmente la responsabilidad "por daños causados", se debe recordar aquí, una vez más, que el artículo 262.5 LSA, hoy 367 TRLSC, no es un supuesto de responsabilidad por daños sino de

23 Para Paniagua Zurera, M., (2005, p. 345), pese a tal silencio legal los administradores deben solicitar la disolución judicial para no incurrir en responsabilidad conforme al artículo 43 de la Ley estatal de Cooperativas, criterio del que discrepamos pues entendemos que la diligencia exigible a los administradores no tienen por qué comprender, cuando el legislador lo ha omitido, el deber de solicitar la disolución judicial de la Cooperativa, toda vez que entendemos que el legislador de Cooperativas estatales, con acierto o sin él que eso en este momento no es relevante, entendió que era bastante con legitimar a cualquier interesado para solicitar la referida disolución judicial -artículo 70.3 in fine de la Ley estatal de Cooperativas-, de modo que los administradores satisfarán un diligente comportamiento con haber convocado la Asamblea General de disolución y sólo serán responsables si no pidieron posteriormente la disolución judicial y ello causó daños a los socios o a terceros. 
responsabilidad sanción ${ }^{24}$. Sólo cabe, pues, estar a la responsabilidad por daños por el cierre de facto de la sociedad cooperativa, cuando resulte que tal cierre de facto fue el que impidió que los acreedores cobrasen sus créditos, pues de haberse realizado una correcta disolución y liquidación sí hubiera sido posible que el acreedor alcanzara el cobro de sus créditos ${ }^{25}$.

2. Una segunda interpretación es considerar que no existe la misma responsabilidad de los administradores en la Ley estatal de Cooperativas que en la LSA en estos mismos supuestos, sin que tampoco sea posible entender que nos encontremos ante una laguna legal susceptible de integración por la LSA, hoy LSC, vía analogía, dada la naturaleza punitiva de la responsabilidad contemplada en el artículo 262.5 LSA, 367 TRLSC, que impide asimismo su interpretación extensiva para aplicarlo a supuestos de hecho ajenos a su dicción literal26.

24 También rechaza Sacristán Bergia, F., "El riesgo de responsabilidad del órgano de administración de las cooperativas en situaciones de insolvencia, y de pérdidas patrimoniales", REVESCO, 89 (2006, pp. 145-146), que el citado precepto de la Ley estatal de cooperativas remita al régimen de responsabilidad por no disolución de las sociedades de capital, lo mismo que defendió la Sentencia del Juzgado de lo Mercantil no 1 de Badajoz de 15 de enero de 2015 (Iltma. Sra. Da. Ester Sara Vila; Id Cendoj: 06015470012015100158 ) y en síntesis de jurisprudencia la Sentencia de la Sección $4^{\text {a }}$ de la Audiencia Provincial de Murcia de 19 de octubre de 2017 (Ponente: Iltmo. Sr. D. Rafael Fuentes Devesa; Id Cendoj: 30030370042017100673), al tiempo que esta última diferenció rotundamente, siguiendo la jurisprudencia recaída en sociedades de capital, entre las acciones de responsabilidad por deudas y de responsabilidad por daños de los administradores.

25 Sentencia de la Sala $1^{\text {a }}$ del Tribunal Supremo de 27 de febrero de 2017 (Ponente: Excmo. Sr. D. Francisco Javier Orduña Moreno; Id Cendoj: 28079110012017100126$)$, que viene a aplicar en sede de Cooperativas el leading case en sociedades de capital que supuso la Sentencia del pleno de la Sala $1^{\text {a }}$ del Tribunal Supremo de 13 de julio de 2016 (Ponente: Excmo. Sr. D. Ignacio Sancho Gargallo; Id Cendoj: 28079119912016100019).

26 Pastor Sempere, C., "La responsabilidad del órgano de administración de las sociedades cooperativas y su necesaria incardinación en el moderno Derecho de sociedades", CIRIEC Revista Jurídica de Economía Social y Cooperativa, 18,(2007, p. 23), y Moya Ballester, J., "Responsabilidad por no promoción de la disolución de los miembros del Consejo Rector", CIRIEC Revista Jurídica de Economía Social y Cooperativa, 18, (2007, pp. 107-122), partiendo la primera de ellas de la negación de la naturaleza sancionadora, siquiera sea civil, de la responsabilidad del artículo $262.5 \mathrm{LSA}$, y el segundo de su atenuación. A favor vid. la Sentencia de la Sección $6^{a}$ de la Audiencia Provincial de La Coruña de 2 de junio de 2009 (Ponente: Iltmo. Sr. D. José Ramón Sánchez Herrero; Id Cendoj: 15078370062009100402), cuando, al aplicar la legislación gallega de cooperativas, sostuvo que "La necesidad de interpretar de forma restrictiva de las disposiciones de carácter sancionador, como las relativas a la exigencia de responsabilidad a los administradores, no permite aplicar de forma analógica o extensiva otros supuestos prevenidos en materia societaria, como la falta de disolución de la cooperativa, existiendo causa legal para ello, al igual que prevén los arts. 262.5 LSA y 105.5 LSRL. Si así lo hubiera querido el legislador autonómico, debería haberlo precisado en la legislación propia, al igual que se hizo en dicha Ley de Cooperativas". 
Esta segunda posible interpretación es acertada, permite que en la legislación estatal vigente de cooperativas los administradores, que incumplen el deber convocar la Asamblea General de disolución por estar incursa la cooperativa en causa de disolución forzosa, no son objeto de sanción específica, y pueden únicamente ser objeto de acciones de responsabilidad por daños, conforme al régimen previsto en los artículos 133 y ss. LSA hoy artículos 236 y ss. LSC- por la remisión que se hace a los mismos en el artículo 43 de la Ley estatal de Cooperativas ${ }^{27}$.

Esta misma interpretación es la que ha de sostenerse al respecto de la responsabilidad de los miembros del órgano de control en las sociedades cooperativas europeas domiciliadas en España que opten por el órgano de administración dual, ya que en tal caso el artículo 15 del Reglamento 1435/2003, relativo al Estatuto de la Sociedad Cooperativa Europea, remite al mencionado artículo 43 de la vigente Ley estatal de

27 Esta es la interpretación, en la doctrina científica, de Morillas Jarillo, M. J. y M. I. Feliú Rey, Vicent Chulià, F. (2005, p. 624) -ya anteriormente el mismo Profesor Vicent Chulià, F. Comentarios al Código de comercio y legislación mercantil especial, (1994, pp. 492-493), al comentar la antigua Ley general de cooperativas-, Beltrán, E., "La responsabilidad de los administradores por obligaciones sociales" (2016) y más en extenso de Sequeira Martín, A. y F. Sacristán Bergia, "Una reflexión sobre la responsabilidad de los miembros del Consejo Rector de las Cooperativas", Revista de Derecho de Sociedades, 21, (2003-2, pp. 222 y 230-231), Vázquez Pena, M. J. (pp. 45-47), Bataller Grau, J., "La disolución de las Cooperativas", Pérdidas, disolución y concurso en sociedades cooperativas, (2012, pp. 117-118) y Vargas Vasserot, C., Derecho de las Sociedades Cooperativas (2014, pp. 419-423), y en la doctrina jurisprudencial de las Sentencias de la Sección $15^{\text {a }}$ de la Audiencia Provincial de Barcelona de 12 de febrero de 2007 (Ponente: Iltmo. Sr. D. Jordi Lluis Forgas Folch; AC 2007/1400), de 24 de abril de 2008 (Ponente: Iltma. Sra. Da $M^{\text {a }}$. Elena Boet Serra; Id Cendoj: 08019370152008100048 ), de 29 de abril de 2008 (Ponente: Iltmo. Sr. D. Jordi Lluis Forgas Folch; Jur. 2008/267451) y 14 de noviembre de 2008 (Ponente: Iltmo. Sr. D. Ignacio Sancho Gargallo; Id Cendoj: 08019370152008100229$)$, en síntesis de jurisprudencia respecto de la legislación cooperativa catalana, de la Sección $3^{\text {a }}$ de la Audiencia Provincial de Valladolid de 9 de abril de 2007 (Ponente: Iltmo. Sr. D. Ángel Muñiz Delgado; Jur. 2007/262950), a propósito de la legislación cooperativa castellano-leonesa, y de la Sección $1^{\text {a }}$ de la Audiencia Provincial de Oviedo de 4 de febrero de 2008 (Ponente: Iltmo. Sr. D. José Ignacio Álvarez Sánchez; Id Cendoj: 33044370012008100073 ), aplicando la legislación estatal. Más confusa es la posición de Paniagua Zurera, M., (pp. 228 y 345-346), pues al tiempo que defiende que el artículo 262.5 LSA no es aplicable a las Cooperativas, también sostiene que los supuestos de hecho de dicho precepto generan responsabilidad patrimonial de los administradores por aplicación del artículo 43 de la Ley de cooperativas, sin aclarar si esa responsabilidad la entiende por daños o de naturaleza punitiva. Por último, Coronado Fernández, F., La Sociedad Cooperativa en la Ley 27/1999, de 16 de julio, de Cooperativas, (2001, pp. 328-331), no adopta postura al respecto, si bien acierta en que la solución a la cuestión viene dada en función de la naturaleza jurídica de la responsabilidad prevista en los artículos 262.5 LSA y 105.5 LSRL, con lo que viene a admitir que si la misma es de responsabilidad sanción no es aplicable a las Cooperativas por la vía de la remisión contenida en el artículo 43 de la Ley estatal de Cooperativas ni tampoco por vía de la extensión del artículo 262.5 LSA a un supuesto de hecho no comprendido en su dicción literal, salvándose así la aprehensión con que refiere el Profesor Vicent Chulià, F., (p. 20, nota 10), la tesis de Coronado Fernández. 
Cooperativas (Fuentes Naharro, 2008, pp. 48-49). Esta interpretación se ve corroborada con el artículo 12 de la Ley 3/2011, de 4 de marzo, por la que se regula la Sociedad Cooperativa Europea con domicilio en España, que directamente remite el régimen de la responsabilidad de los miembros de su órgano de administración al de los administradores de las S.A., si bien es cierto que, por razones sistemáticas y temporales de la nueva ley debió hacer remisión al de los administradores de las sociedades de capital, anónimas y limitadas.

\section{Un nuevo régimen jurídico a la palestra: el asturiano}

En los últimos años han visto la luz el anteproyecto de Ley de Sociedades Cooperativas del Principado de Asturias ${ }^{28}$, más tarde el proyecto de Ley del Principado de Asturias de Sociedades Cooperativas ${ }^{29}$ (06/0142/0021/10019); y, tras haberse agotado esa legislatura sin haberse aprobado, el posterior proyecto de Ley del Principado de Asturias de Sociedades Cooperativa (07/142/0010/06695)30. Finalmente, tras un largo camino de más de cuatro años, se desembocó en la aprobación de la Ley del Principado de Asturias 4/2010, de 29 de junio, de Cooperativas (LCPA) y que ha supuesto, según veremos seguidamente, una novedad más en el panorama legislativo cooperativo español.

Para los asturianos reviste particular interés el análisis de la citada LCPA, pero en general para todos los estudiosos de las cooperativas en España es interesante dicho análisis por las novedades que incluye. Es más, su interés trasciende al derecho de sociedades de capital, tan polémico en esta materia.

En primer lugar, la legislación asturiana remite el tratamiento de la insolvencia de la Cooperativa, por pérdidas o por cualquier otra causa, a lo dispuesto en la legislación concursal (artículo 117.2 LCPA), sin configurar la citada insolvencia como causa de disolución forzosa de la cooperativa asturiana.

Por otra parte, respecto de las causas de disolución forzosa, el artículo 118 LCPA establece las siguientes obligaciones para el órgano de administración -puede ser un

28 Que fue objeto del dictamen 2/2006, sobre el Anteproyecto de Ley de Sociedades Cooperativas del Principado de Asturias, de 17 de abril de 2006 (Disponible en: www.cesasturias.es), que no contiene referencia alguna en relación con la materia objeto de este trabajo.

29 Ver más en el proyecto de Ley 06/0142/0021/10019, Boletín Oficial de la Junta General del Principado de Asturias, 13 de julio de 2006, VI Legislatura, núm. 31-1.

30 Ampliar en el proyecto de Ley 07/0142/0010/06995, Boletín Oficial de la Junta General del Principado de Asturias, 19 de enero de 2009, VII Legislatura, núm. 22.1. 
administrador único, dos solidarios, dos mancomunados o un Consejo Rector, conforme al artículo 59.1 del Proyecto de Ley-, ya previstas en otros ordenamientos autonómicos:

1. Obligación de convocar, en el plazo de treinta días - nuevamente hay que suponer que se trata de días naturales conforme al artículo 5.1 CC y ante la falta de previsión diferente y expresa al respecto en el texto legal aprobado-, Asamblea General de disolución (artículo 118.1 LCPA ${ }^{31}$ ). No concreta tampoco el citado precepto el dies a quo del plazo de treinta días referido, entendiendo que la sistemática del propio precepto acepta que el plazo empieza a contar cuando concurra la causa de disolución, no cuando el órgano de administración conociera o hubiera debido conocer su concurrencia. El acierto de tal previsión es, cuando menos, discutible, y se deja apuntada la posibilidad de que la interpretación jurisprudencial integre la laguna legal en el sentido de remitirse a la fecha del deber de conocimiento, pues es fácil que la jurisprudencia se vea influenciada por el criterio jurisprudencial dominante que se ha referido con anterioridad en éste y en otros trabajos.

2. Obligación de solicitar la disolución judicial cuando el acuerdo de la Asamblea General fuese contrario a la disolución o no pudiera ser logrado. Tal solicitud deberá formularse en el plazo de dos meses contados desde la fecha prevista para la celebración de la asamblea que no se hubiese celebrado o desde el día de la celebración de la asamblea en la que se adoptara el acuerdo contrario a la disolución o el mismo no se hubiera adoptado (artículo 118.4 LCPA ${ }^{32}$ ). Nuevamente, respecto de otras leyes autonómicas,

31 "Cuando concurra cualquiera de las causas de disolución previstas en las letras b), c), d), e) y g) del apartado 1 del artículo anterior, el órgano de administración deberá convocar, en el plazo de treinta días, la asamblea general para que adopte el acuerdo de disolución. Con este fin, cualquier socio podrá requerir al órgano de administración para que convoque la asamblea general, si a su juicio existen algunas de las mencionadas causas de disolución".

32 "El órgano de administración está obligado a solicitar la disolución judicial de la cooperativa cuando el acuerdo social fuese contrario a la disolución o no pudiera ser logrado. La solicitud de disolución habrá de formularse en el plazo de dos meses a contar desde la fecha prevista para la celebración de la asamblea, cuando ésta no se haya constituido, o desde el día de la asamblea, cuando el acuerdo hubiese sido contrario a la disolución o no se hubiera aceptado". Hay que sobreentender que para que concurra la obligación de instar la disolución judicial es preciso que debe subsistir la causa legal de disolución forzosa, algo que en su momento Alejandro Alvargonzález Tremols, compareciente ante la Comisión de Industria y Empleo de la Junta General del Principado de Asturias en la sesión del 30 de junio de 2009, como técnico jurídico en la materia (Junta General del Principado de Asturias. Diario de Sesiones, año 2009, Serie C, VII Legislatura, núm. 191), sugirió que habría de preverse expresamente, como de hecho luego propuso la enmienda con registro de entrada $n^{\circ}$ 9.4049, del Grupo Parlamentario Popular (Junta General del Principado de Asturias. Boletín Oficial, 16 de marzo de 2010, VII Legislatura, 
falta la previsión de la posibilidad de que no haya que solicitar la disolución judicial porque el acuerdo de disolución no se adoptara dado que la causa de disolución hubiera desaparecido o se hubiese enervado.

Partiendo de la existencia de las citadas obligaciones, y al igual que ocurre en uno de los sistemas en que se ha ordenado la legislación autonómica española, la LCPA no previene ningún régimen especial de responsabilidad para los administradores de las cooperativas asturianas que hubiesen incumplido cualquiera de las obligaciones de convocatoria o de solicitud de disolución judicial mencionadas. Ahora bien, no por ello hay que pensar que los administradores de las cooperativas asturianas son por completo inmunes a su actuación posterior a la concurrencia de una causa de disolución forzosa, pues en ese caso la situación asturiana actual es como la estatal, atinente a las sociedades de capital anterior a 1989 -un regreso al pasado hacia un tiempo más de veinte años anterior-, de modo que se les podrá exigir por los acreedores responsabilidad por la vía del ejercicio de una acción directa, cuando acrediten que el comportamiento de tales administradores ulterior a la concurrencia de la causa disolutoria fue negligente y que, como consecuencia de ello, se les generaron daños y perjuicios cuya reparación podrán obtener por tal vía ${ }^{33}$.

La otra novedad importante del sistema asturiano, junto con el tratamiento específico de la insolvencia en materia de disolución a la luz de la vigente legislación concursal española, aparece en el artículo 119 LCPA, que por su novedad e importancia conviene reproducir literalmente: "El incumplimiento de lo dispuesto en la legislación

núm. 22.9), pero cuya omisión tampoco entendemos que no pueda salvarse fácilmente con una interpretación lógica y sistemática del texto legal; el citado compareciente también sugirió que el artículo 80 de la Ley de Cooperativas de Asturias contuviese también la causa legal de disolución por pérdidas que redujesen el patrimonio neto por debajo de la mitad de la cifra del capital social, previsión ésta, sin duda, de mayor relevancia práctica, que fue también defendida por la enmienda con registro de entrada $n^{\circ}$ 9.408, del Grupo Parlamentario Popular (Junta General del Principado de Asturias. Boletín Oficial, 16 de marzo de 2010, VII Legislatura, núm. 22.9), que propuso la adición de una nueva causa de disolución forzosa, bajo el epígrafe del artículo 107, que dijese "Por reducción del patrimonio neto de la sociedad por debajo del cincuenta por ciento de la cifra del capital social, salvo que en el plazo de dos meses se restablezca el equilibrio patrimonial", enmienda que recuerda al artículo 260.1.4 LSA, pero que, no sabemos si por descuido o intencionadamente, era mucho más rigurosa que este último precepto societario citado, toda vez que en el mismo se permite la enervación con el aumento o reducción del capital social en medida suficiente para que el patrimonio neto supere la mitad del capital social en tanto que la enmienda asturiana exigía el restablecimiento del equilibrio entre patrimonio neto y capital social, esto es, que el patrimonio neto estuviese, como mínimo, al mismo nivel que el capital social.

33 En general, a propósito de las legislaciones autonómicas que no contienen una responsabilidad sanción por no disolución forzosa, y en el mismo sentido antes expuesto por nuestra parte, vid. Sacristán Bergia, F. (pp. 154-159). 
concursal en orden a la solicitud de concurso, determinará la responsabilidad solidaria de los administradores por las deudas nacidas a partir del momento en que surja la situación de insolvencia. La responsabilidad de los administradores prescribe a los cuatro años desde que pudo ser ejercitada la acción".

El artículo 119 supone el nacimiento de un nuevo supuesto de responsabilidad de los administradores en las cooperativas españolas, que recuerda en parte a los entonces vigentes artículos 262.5 LSA y 105.5. LSRL, pero sólo para los supuestos de insolvencia y no solicitud de concurso de la sociedad insolvente.

Así pues, interpretando el artículo 119, que debe ponerse en conexión con el vigente artículo 5 bis LC, consideramos que:

1. El presupuesto fáctico desencadenante de la responsabilidad es que la sociedad cooperativa se encuentre, al menos, en el estado de insolvencia que motiva el deber del deudor de declararse en concurso necesario (artículos 2 y 5 LC). Por nuestra parte éramos partidarios a la vista de la redacción inicial del artículo 5 LC, aunque somos conscientes de que se trata de una posición minoritaria en la doctrina española que busca apoyo en su mayoría en la exposición de motivos de la LC para seguir la tesis contraria. A saber, que también los deudores en situación de insolvencia inminente estaban obligados a solicitar su declaración de concurso necesario, dado que el artículo 5.1 LC se limita a decir que "el deudor deberá solicitar la declaración de concurso dentro de los dos meses siguientes a la fecha en que hubiera conocido o debido conocer su estado de insolvencia", sin añadir más calificativos a este último sustantivo, de modo que no restringe su ámbito de aplicación a la insolvencia actual. En el presente, con la redacción actual del artículo 5 bis LC entendemos que el legislador quiere que sólo haya deber de solicitar el concurso cuando concurre una situación de insolvencia actual, pero, en todo caso, para evitar el problema interpretativo descrito no estaría de más que el legislador asturiano aprovechase para concretar a qué insolvencia se está haciendo referencia al redactar el artículo 119 LCPA, esto es, sólo a la actual o también a la inminente.

2. Se presupone que el deber de solicitar el concurso voluntario de la cooperativa insolvente es de los administradores, tal y como lo decía el artículo 3.1 segundo párrafo LC, hasta la sorprendente reforma de la Ley 14/2013, de 27 septiembre, de apoyo a los emprendedores y su internacionalización. Esta ley llevó a cabo, en su artículo 21, una reforma de diversos preceptos de la LC, que comprendió el artículo 3.1 LC, al incorporar la legitimación 
para solicitar el concurso del mediador concursal, lo que fue fruto de la adición del acuerdo extrajudicial de pagos y del concurso consecutivo (artículos 231 a 242 LC). Hasta aquí parece que en nada afectaría en nuestro objeto de estudio. El problema estriba en que, en la citada reforma de 2013 de la LC, se eliminó el artículo 3.1.2 LC, con lo que se podría volver a abrir el debate sobre la competencia exclusiva de la Asamblea General para solicitar la declaración de concurso, privando de legitimación a tal efecto al órgano de administración. Se plantea, pues, una disfunción entre la legislación cooperativa asturiana y la concursal estatal, al menos hasta que no tenga lugar una reforma legal expresa de la LC o bien una interpretación jurisprudencial consolidada de la misma que interprete la reforma de 2013 en el sentido de que, en realidad, lo único que se modificó fue el párrafo primero del artículo 3.1 LC, no habiendo querido el legislador dejar sin efecto el párrafo segundo, por ser la única finalidad de dicha reforma adicionar la legitimación del mediador concursal más no eliminar la del órgano de administración o liquidación ${ }^{34}$. En todo caso, habría que aprovechar para concretar qué ocurre en los supuestos de administración mancomunada o Consejo Rector, al objeto de determinar si es posible que uno solo de los administradores pueda solicitar el concurso y con ello salvar su responsabilidad y la de los demás por aplicación del artículo 119 LCPA analizado. Queda, además, al margen la interpretación de un sector de la doctrina, a propósito de la legislación estatal y que pudiera tener también su proyección sobre la normativa autonómica, a la que no le parece descabellado concluir que el deber de convocar la asamblea para solicitar la declaración de concurso en caso de insolvencia de la sociedad -o el deber de solicitar directamente dicha declaración cuando no se alcance un acuerdo de la asamblea- integra el deber general de diligencia de los administradores de la sociedad cooperativa, de modo que su incumplimiento, entonces, podría desencadenar su responsabilidad frente a la sociedad, los socios y los terceros (Tato Plaza, et al., 2013).

3. El ámbito subjetivo de la responsabilidad solidaria comprende a los administradores que no hubiesen solicitado el concurso necesario en el plazo de los dos meses previstos en el artículo 5.1 LC, que se entiende ampliados a seis meses para el caso de existir un preconcurso del artículo 5 bis LC. En este punto convendría que la ley definitiva fuera más clara y así

34 A favor de la reforma legislativa está, por ejemplo, Fernández Larrea (2013). 
concretara si la solidaridad comprende a los administradores entre sí y con la cooperativa.

4. El ámbito objetivo de esta nueva responsabilidad viene concretado en las deudas sociales nacidas a partir del momento en que surja la situación de insolvencia. De nuevo falta precisión en el precepto, por lo que sería conveniente que:

a) Delimitara qué se entiende por deudas sociales nacidas, para salvar así los problemas que plantea actualmente la legislación estatal de sociedades de capital vigente.

b) Concretará a qué insolvencia se está haciendo referencia, sólo a la actual o también a la inminente

c) Especificara que la fecha a tener en cuenta debe ser la del incumplimiento del deber de solicitud de concurso voluntario (Morillas Jarillo, 2016).

5. La naturaleza jurídica de la responsabilidad es punitiva o sancionadora, toda vez que no se exige ni culpa, ni daños, ni relación de causalidad entre una y otros.

6. Por último, se establece un régimen particular de prescripción, completamente novedoso, aunque recuerda en parte al artículo 949 C. Com., y anticipa el vigente artículo 241 bis LSC, que se cuantifica en cuatro años contados desde que se pudo ejercitar la acción de responsabilidad, esto es, con carácter general, desde transcurrieran los dos meses contados desde la insolvencia de la sociedad cooperativa sin que los administradores hubiesen solicitado la declaración de concurso de la cooperativa y con carácter particular, para el supuesto de aplicar el caso del artículo 5 bis LC -recordamos que negociándose una propuesta anticipada de convenio o una refinanciación-, desde el día de vencimiento del plazo semestral que se desprende del mismo - dos meses para comunicar el inicio de las negociaciones para la adhesión a la propuesta anticipada de convenio, más tres meses para seguir esas negociaciones y un mes adicional para solicitar la declaración de concurso-. Por tanto, se da la peculiaridad de que los administradores responderán, en realidad, de deudas sociales no prescritas durante un plazo máximo de cuatro años y dos meses -o seis meses, según los casos antes expuestos-, ya que también responden de las deudas contraídas entre el día de la insolvencia y el día del vencimiento del plazo bimensual en el que habrán incumplido 
su deber de solicitar la declaración de concurso necesario de la cooperativa que administran.

Esta solución asturiana viene a añadir complejidad a la situación existente, al mismo tiempo que pone de manifiesto una circunstancia compleja. A saber, la imperiosa necesidad de coordinar la responsabilidad de los administradores en los derechos concursales y de sociedades, al objeto de alcanzar un régimen jurídico único, que evite la duplicidad actual. No se debe olvidar que los administradores de las cooperativas, y entre ellos los de las cooperativas asturianas, también están sujetos a las responsabilidades concursales y peculiaridades de responsabilidad de administradores previstas en los artículos 48 ter y quáter, 60.2 y $3,172.2 .3^{\circ}$ y 172 bis LC, con todos los conflictos que ello está generando en la práctica concursal y societaria española. Así, baste tener en cuenta la proximidad que existe entre el supuesto de hecho desencadenante de la responsabilidad del artículo 119 LCPA y el del artículo 172 bis LC ${ }^{35}$, en la medida en que este último se basa en:

1. La calificación de un concurso como culpable.

2. A su vez, el concurso se califica como culpable cuando en la causación o agravación de la insolvencia hubiera mediado dolo o culpa grave del deudor (artículo 164.1 LC).

3. Hay presunción iuris tantum de dolo o culpa grave cuando los administradores hubieran incumplido el deber de solicitar la declaración del concurso (artículo $165.1^{\circ} \mathrm{LC}$ ).

Como se ve, al final se llega a un supuesto de hecho que es idéntico entre la legislación concursal estatal y la cooperativa asturiana, el que los administradores hayan incumplido el deber de solicitar la declaración de concurso, pero con la diferencia de que el ámbito objetivo de la responsabilidad es muy diferente en uno y otro caso. En la legislación concursal se responde del déficit concursal, esto es, de los créditos que los acreedores concursales y contra la masa, total o parcialmente, no perciban en la liquidación de la masa activa. 


\section{Conclusiones}

La simple lectura de las quince disposiciones legales -y en tránsito hacia dieciocho- de derecho interno español, muchas de ellas diferentes hasta el punto de poder hablar, al menos, de hasta seis sistemas de responsabilidad, que hoy son aplicables a las sociedades cooperativas en España en la materia objeto de estudio revela, sin necesidad de mayores disquisiciones y como ejemplo paradigmático, palpablemente el laberinto que es en la actualidad la legislación española en materia de cooperativas ${ }^{36}$. De hecho, para un abogado español que se dedique en toda España a las cooperativas requiere del estudio de casi tanto volumen de legislación como si se dedicase a esa materia dentro de toda la Unión Europea, lo que, a nuestro juicio, no deja de ser un peligroso elemento generador de inseguridad jurídica, amén de un fenómeno rupturista con la unidad de mercado en España.

Los diferentes sistemas en que se han podido agrupar las leyes estatales y autonómicas muestran que el grado de diversidad del tratamiento de la materia es muy acusado, pues se llega al tope de ir de la ausencia de regulación específica e

36 No es sólo ya que como dijo el Profesor Vicent Chulià, "la legislación cooperativa española ha adquirido una gran complejidad" (al confluir la legislación comunitaria del Reglamento $\mathrm{n}^{\circ}$ 1435/2003, del Consejo, de 22 de julio de 2003, relativo al Estatuto de la Sociedad Cooperativa Europea, la legislación estatal y la pléyade de Leyes autonómicas", sino que como también señaló poco más adelante el mismo autor citado, (p. 618), estamos ante un verdadero "despropósito legislativo" -"dislate legislativo", como dice en similar sentido Arroyo Martínez, l., (1997, p. 50) - o como también indicó en "El futuro de la legislación cooperativa", CIRIEC, Revista Jurídica de Economía Social y Cooperativa, 13, (2002c, p. 19), ante un ejemplo de "polución legislativa". Además, debe tenerse en cuenta el problema que plantea la aplicación del citado Reglamento comunitario, cuyo artículo 8.1.c.iii, como destacan Uría Menéndez, R., A. Menéndez Menéndez y M. Vérgez Sánchez, en Uría-Menéndez (2006, p. 1425), remite a la aplicación de Ley del Estado miembro del domicilio social -en particular, en materia de responsabilidad de administradores vid. la remisión a la legislación del Estado miembro donde se encuentre el domicilio social que realiza el artículo 51 del Reglamento comunitario, pero sólo respecto de la responsabilidad por daños causados a la propia Sociedad Cooperativa Europea-, siendo más que discutible que por esa vía se pueda llegar a la aplicación de la legislación autonómica del domicilio social, pues en la práctica, como bien expone Lambea Rueda, $(2006$, p. 2), se llega a la posibilidad de que si una sociedad cooperativa tiene su domicilio en una comunidad autónoma, su actividad principal en otra y a la vez es Sociedad Cooperativa Europea quedaría sujeta en el ámbito europeo al reglamento comunitario y supletoriamente a la legislación autonómica de su domicilio, por remisión del Reglamento comunitario, y en el ámbito español a la legislación autonómica del lugar de su actividad principal, por remisión de la Ley estatal de Cooperativas, situación absurda que admite dos posibles soluciones de lege data: que el domicilio social al que se refiere el artículo 8 del Reglamento comunitario es España, siendo la Ley estatal la que debe regir, o bien se entienda que la Comunidad Autónoma equivaldría a un Estado para considerar que la ley del domicilio social es la del Estado-Comunidad Autónoma, acentuando ello lo que Lambea Rueda califica de singular "torre de Babel". De hecho, en la doctrina española Morillas Jarillo (2002, p. 4811) ha llegado hablar de la esquizofrenia que supone la unidad europea y la dispersión legislativa autonómica en materia de Cooperativas, ello después de haber defendido, (2002, p. 4757), que las leyes autonómicas deberían ser declaradas inconstitucionales y que "la mejor Ley autonómica reguladora del régimen jurídico-privado de la Sociedad Cooperativa es la que no existe". 
inexistencia de responsabilidad hasta la responsabilidad sanción por todas las deudas sociales. Además, los sistemas analizados presentan interrelaciones entre sí, de modo que no son completamente diferentes en lo que se refiere a la situación del administrador frente a la causa de disolución forzosa, introduciéndose diferencias a las que no se les encuentra otra justificación que, en algunas ocasiones, un afán de singularizarse para tratar de justificar lo injustificable; ¿qué si no se puede decir que unas leyes fijen un plazo de un mes y otras de treinta días para que los administradores convoquen la Asamblea General de disolución?, ¿qué diferencia tan sustancial hay entre un mes y treinta días, unas veces hábiles y otras naturales para mayor diversidad, como para justificar que deba existir una ley autonómica esté a uno de esos plazos y otra al otro con el riesgo de que los asesores jurídicos los confundan y con ello puedan confundir a los propios administradores? En gran parte de las diferencias existentes entre las diversas leyes autonómicas y entre las mismas, y la Ley estatal, fuera de lo que es la determinación de la existencia o no de responsabilidad de los administradores y su ámbito objetivo, no existe ni una justificación de competencia vertical -entre las formas jurídicas europea, de un lado, y estatales y autonómicas, de otro- y horizontal -entre los diversos legisladores regionales y estatal- ${ }^{37}$ que conduzca al efecto óptimo o "efecto Delaware", como instrumento que tienda a la captación de la actividad emprendedora en el territorio de la comunidad autónoma mediante el establecimiento de un régimen legal que ampare, proteja e impulse dicho espíritu $^{38}$. En todo caso, se corre el riesgo además de que, al final, la competencia de sistemas normativos sea una "race to the bottom", en la que los administradores pugnen por ubicar las cooperativas por ellos administradas bajo el paraguas del régimen jurídico menos gravoso para ellos que será, al fin y a la postre, el menos tuitivo para los acreedores sociales.

37 Siguiendo la ordenación de competencias que aporta Vicent Chulià, (2003, pp. 61-62).

38 Ya Vicent Chulià reconoció que dicha competencia entre Leyes no siempre conduce en esta materia al referido efecto óptimo y en otro trabajo más reciente, "Las misiones del Derecho mercantil en el siglo XXI", (2010, pp. 93-94), reiteró su recomendación de evitar la fragmentación legislativa del Derecho privado mediante Leyes marco y Leyes de armonización ex artículo 150 CE. Es más, por nuestra parte, entendemos que en este ámbito el efecto óptimo es la regulación estricta de la responsabilidad de los administradores ya que ello determinará la existencia de Sociedades Cooperativas en funcionamiento no simplemente aparente y la depuración de las incursas en causas de disolución, lo que redundará en el prestigio de las Cooperativas sujetas a regímenes jurídicos estrictos $\mathrm{y}$, a su vez, determinará que las mismas puedan contratar en mejores condiciones, pues los acreedores les exigirán menos garantías y les ofrecerán mejores condiciones, dado que a la solvencia de la propia Cooperativa irá aparejada, en su caso, la responsabilidad solidaria de sus administradores y todo ello, a su vez, operará como un elemento de atracción a los emprendedores que acudirán a donde rija ese sistema jurídico porque se beneficiarán de la explotación de la actividad económica de la Cooperativa en mejores y más rentables condiciones económicas. 
Una solución de futuro imprescindible debe ser armonizar la legislación de cooperativas en España vía artículo 150.3 CE ${ }^{39}$, una vez fracasada en esa función la vigente Ley estatal de Cooperativas ${ }^{40}$, y dicha armonización, en esta materia concreta, debe venir por el establecimiento de una responsabilidad punitiva de los administradores que incumplan las obligaciones de convocar asamblea de disolución y, en su caso, de instar la disolución judicial de la sociedad cooperativa. Tal solución es la más acertada por las siguientes razones:

a) Porque la práctica ha revelado que permite una depuración del parque societario capitalista español y una evidente mejora de la calidad de la administración de las sociedades de capital españolas en las dos últimas décadas, funciones que deberían trasladarse al marco de las cooperativas.

b) Porque permitiría la competencia en condiciones de igualdad en el mismo mercado de sociedades de capital y sociedades cooperativas ${ }^{41}$ y de estas últimas entre sí, máxime teniendo en cuenta el principio de no discriminación instaurado por el artículo 9 del Reglamento de la Sociedad Cooperativa Europea que conduce a la paradoja de la situación actual en que no se puede discriminar el tratamiento de sociedades cooperativas europeas respecto de las españolas en España pero sí se discrimina el tratamiento de las sociedades cooperativas españolas en función del territorio en que realizan su actividad principal.

39 Con ello nos sumamos a lo que se sostiene generalmente por la doctrina científica española, tal y como recordó, con síntesis de doctrina al respecto, Paniagua Zurera (2005-1, p. 200) y Sánchez Pachón, (2007, pp. 264 y 273).

40 Cuyo ámbito de aplicación es reducidísimo, como advierte Vicent Chulià -también Uría Menéndez, R., A. Menéndez Menéndez y M. Vérgez Sánchez, en Uría-Menéndez, al quedar circunscrito a las que denomina "Cooperativas nacionales" -que desarrollen su actividad en el territorio de más de una comunidad autónoma y sin tener su actividad principal en una de ellas - y a las cooperativas de Ceuta y Melilla, hasta el punto de convertirse en lo que muy gráficamente denomina "Derecho Romano de las Cooperativas".

41 Vicent Chulià (2002, p. 375), (2008, pp. 115 y 117), arguyó a la aplicación del principio de igualdad entre la LSA y la Ley estatal de Cooperativas para defender la derogación del régimen de la LSA en este punto, pero por nuestra parte consideramos que el citado principio es una vía de doble sentido, de modo que también puede justificar derogar el régimen de la Legislación estatal de Cooperativas, ya que la solución debe venir dada en función de la igualdad en la solución que se estime más satisfactoria y ello incluso, como seguidamente sostenemos, a favor de un sistema unificado mejor en los dos ámbitos, sociedades de capital y cooperativas.

En la práctica se apreció ya dicha discriminación por la Sentencia de Sección $1^{\text {a }}$ de la Audiencia Provincial de Vizcaya de 18 de febrero de 2005 (Ponente: Iltmo. Sr. D. Fernando Valdés-Solis Cecchini; AC 2005/612), aunque de forma equivocada pretendió eliminar la misma mediante la aplicación del artículo $262.5 \mathrm{LSA}$ a una sociedad cooperativa vasca, cuyo régimen autonómico, como ya hemos visto, no contiene la responsabilidad sanción aplicable a los administradores de las S.A. 
c) Porque se alcanzaría una mejor protección de los participantes en el mercado, especialmente de los acreedores de las mencionadas cooperativas.

d) Porque, teniendo en cuenta que la Ley estatal de Cooperativas significó un avance en la profesionalización de los administradores de las sociedades cooperativas vía su acercamiento a los administradores de las sociedades de capital en materia de retribución, entendemos que lógica consecuencia de ello es que tal profesionalización se acompañe de una exigencia de responsabilidades en línea con las exigidas a los administradores de tales sociedades capitalistas ${ }^{42}$.

Llegados a este punto simplemente resta añadir que además somos defensores de que la armonización debería ir en el sentido de ampliar el ámbito objetivo de la vigente responsabilidad de los administradores de las sociedades de capital con el fin de no discriminar entre acreedores anteriores y posteriores a la concurrencia de la causa de disolución. Que amén de resultar semillero de conflictos acerca de la determinación de la anterioridad o posterioridad referidas, implica una flagrante discriminación en perjuicio de los acreedores más antiguos que beneficia a los más recientes o más modernos.

También es conveniente que en la legislación de cooperativas se tratase expresamente el tema de la responsabilidad del administrador de hecho y del administrador persona jurídica en esta sede de responsabilidad por no disolución.

Por último, destacar que donde sí hay unificación en materia de responsabilidad de administradores de cooperativas y de sociedades de capital es en el supuesto de que unas y otras estén sujetas a procedimiento concursal. En tal caso también los administradores de las sociedades cooperativas están sujetos a la responsabilidad contemplada en los artículos $172.2 .3^{\circ}$ y 172 bis LC, así como a la medida cautelar del posible embargo de sus bienes que se prevé en el artículo 48 ter LC ${ }^{43}$. Esta

42 Sobre la profesionalización de los administradores de las cooperativas en cuanto a su retribución, ver Tusquets Trías de Bes, (2000, pp. 49-60). Posteriormente, vid. la Sentencia de la Sala $1^{\text {a }}$ del Tribunal Supremo de 4 de junio de 2002 (Ponente: Excmo. Sr. D. Román García Varela; RJA 2002/4584), que haciendo aplicación de la legislación estatal anterior a la Ley de 1999, anterior por tanto al incremento de profesionalización, no tuvo en cuenta el hecho de que los administradores eran "agricultores, miembros además de una Cooperativa de base, personas poco acostumbradas a la actividad comercial o mercantil propiamente dicha, que acuden a las reuniones periódicamente, sin actuar en el día a día de la Cooperativa, con más voluntad que otra cosa y sin posibilidad, muchas veces, de conocer el funcionamiento real de la entidad, funcionamiento llevado a cabo por Directores o Gerentes comerciales en los que se delegaban las funciones", al entender que habían faltado a la más elemental prudencia exigida a un administrador y habían procedido sin más al cierre de la Cooperativa.

43 No sólo, por tanto, al originario artículo 48.3 LC, hoy artículo 48 ter LC tras la Ley 38/2011 como refieren en la doctrina Sequeira Martín, A. y F. Sacristán Bergia. 
uniformidad se rompe con la Ley de Cooperativas de Asturias, que pone de manifiesto la necesidad de dar una regulación única, ya en el Derecho de sociedades, ya en el Derecho concursal a la responsabilidad de los administradores de las sociedades insolventes. La solución asturiana de exigirles responsabilidad por las deudas posteriores a la situación de insolvencia es una opción, aunque sería mejor hacerles responsables de todas las deudas sociales, al objeto de no hacer de mejor condición a los acreedores más recientes en detrimento de los más antiguos, que, muchas veces, además con sus esperas y admisión de morosidades pueden haber ayudado a que la cooperativa continuase en funcionamiento, viéndose luego preteridos a favor de acreedores más recientes que ningún esfuerzo especial ni sacrificio han realizado a favor de su deudora.

\section{Referencias}

Arroyo Martínez, I. (1997). Comentarios a la Ley de Sociedades de Responsabilidad Limitada. En I. Arroyo Martínez y J. M. Embid Irujo (Coord.). Madrid, España: Tecnos.

Bartalini, G. (2000). La responsabilità degli amministrattori e dei direttori generali di società per azioni. Torino: UTET.

Bataller Grau, J. (2012). La disolución de las Cooperativas", Pérdidas, disolución y concurso en sociedades cooperativas. Madrid, Barcelona, Buenos Aires, Sâo Paulo: Marcial Pons.

Bianchi, G. (1998). Gli amministratori di società di capitali. Milán: Cedam.

Bonelli, F. (1991). La responsabilità degli amministratori. En G. E. Colombo y G. B. Portale (Dir.). Trattato delle Società per Azioni. Torino: Unione Tipográfico-Editrice Torinese.

Casella, M y Ruozi, R. (1997). L’Amministratore di società. Milán: EGEA.

Coronado Fernández, F. (2001). La Sociedad Cooperativa en la Ley 27/1999, de 16 de julio, de Cooperativas. En F. J. A. Espinosa (Coord.). Granada: Comares.

D’Angelo, F. (1994). Perdita integrale del capitale sociale: conseguenze e ricostituzione. Giurisprudenza Commerciale, mayo-junio.

Fernández Larrea, I. (2013). Quiebra de la legitimación concursal. AJA, 874. Recuperado de: www. westlawinsignis.es. 
Fuentes Naharro, M. (2008). La opción por el sistema dual de administración en la Sociedad Cooperativa Europea domiciliada en España. Universidad Complutense de Madrid. Recuperado de: www.ucm.es/eprints.

Galgano, F. (1998-1999). Diritto Commerciale. Le Società, Zanichelli. Bologna: edizione.

Gambino, A. (1994). La valutazione del rischio della responsabilità civile di amministratori e managers nelle società per azioni. Assicurazioni, marzo-junio.

Jaeger, P. G. y Denozza, F. (1997). Appunti di Diritto Commerciale. Milán.

Lambea Rueda, A. (2006). Marco jurídico de la Sociedad Cooperativa Europea domiciliada en España. La Ley, 6479.

Morillas Jarillo, M.J. (2002). El ámbito de aplicación de las Leyes de Sociedades Cooperativas. Derecho de sociedades. Libro homenaje al Profesor Fernando Sánchez Calero. Madrid: McGraw-Hill.

Morillas Jarillo, M.J. (2016). La responsabilidad de los administradores de las Sociedades Cooperativas: mosaico legal e interpretación judicial. Ciriec-España, Revista Jurídica, 28. Recuperado de: http://www.ciriec-revistajuridica.es/index.php?id_pagina=8\&idRevista=31.

Morillas Jarillo, M.J. y Feliú Rey, M.I. (2002). Curso de Cooperativas. Madrid: Tecnos.

Moya Ballester, J. (2007). Responsabilidad por no promoción de la disolución de los miembros del Consejo Rector. CIRIEC Revista Jurídica de Economía Social y Cooperativa, 18.

Paniagua Zurera, M. (2005). Las Sociedades Cooperativas. Las Sociedades Mutuas de Seguros y las Mutualidades de Previsión Social, Tratado de Derecho Mercantil. En M. Olivencia, C. FernándezNòvoa y R. Jiménez de Parga (Dir.). Madrid, Barcelona: Marcial Pons.

Paniagua Zurera, M. (2005). La determinación y la distribución de los resultados del ejercicio económico en la Sociedad Cooperativa: propuestas de armonización legislativa. RdS, 24.

Paniagua Zurera, M. (2008). Las empresas de inserción en la Ley estatal 44/2007, de 13 de diciembre, reguladora de las empresas de inserción. CDC, 49.

Pastor Sempere, C. (2007). La responsabilidad del órgano de administración de las sociedades cooperativas y su necesaria incardinación en el moderno Derecho de sociedades. CIRIEC Revista Jurídica de Economía Social y Cooperativa, 18. 
Picciau, A. (1997). Il divieto di nuove operazioni nella fase di liquidazione delle società. Studi in onore di Gastone Cottino. Milán: Cedam.

Piselli, D. (2003). La responsabilità degli amministratori verso la società alla vigilia della riforma. Le Società, 9.

Prendes Carril, P. (1996). Pérdidas y Responsabilidad Civil de los Administradores en las Sociedades de Capital. Ilustre Colegio de Abogados de Gijón.

Sacristán Bergia, F. (2006). El régimen del proceso disolutorio extintivo de las sociedades cooperativas agrarias y las sociedades agrarias de transformación. En J. Pulgar Ezquerra (Dir.). Cooperativas agrarias y Sociedades Agrarias de Transformación. Madrid: Dykinson.

Sacristán Bergia, F. (2006). El riesgo de responsabilidad del órgano de administración de las cooperativas en situaciones de insolvencia, y de pérdidas patrimoniales. REVESCO, 89.

Sequeira Martín, A. y Sacristán Bergia, F. (20003). Una reflexión sobre la responsabilidad de los miembros del Consejo Rector de las Cooperativas. Revista de Derecho de Sociedades, 21.

Sánchez Pachón, L. A. (2007). Cuestiones generales sobre la Ley de Cooperativas de Castilla y León. RJCL, 13(agosto).

Suárez-Llanos Gómez, L. (1996). La responsabilidad por deudas de los administradores de Sociedad Anónima. En Estudios Jurídicos en homenaje al Profesor Aurelio Menéndez. Sociedades mercantiles. Madrid: Civitas.

Tato Plaza, A., et al. (2013). Tratado de Cooperativas. Valencia: Tirant lo Blanch. Recuperado de: www.tirantonline.com.

Tusquets Trías de Bes, F. (2000). La profesionalización de los cargos directivos en la nueva Ley de Cooperativas. RGD, 664-665(enero-febrero).

Uría Menéndez, R., A. Menéndez Menéndezy Vérgez Sánchez, M. (2006). Curso de Derecho Mercantil. En Uría-Menéndez. Madrid.

Vargas Vasserot, C. (2014). Derecho de las Sociedades Cooperativas. Madrid: La Ley.

Vázquez Pena, M. J. (2007). La aplicación del apartado quinto del artículo 262 del Texto refundido de la Ley de Sociedades Anónimas a las Sociedades Cooperativas. CIRIEC Revista Jurídica de Economía Social y Cooperativa, 18. 
Vicent Chulià, F. (1994). Comentarios al Código de comercio y legislación mercantil especial. Tomo XX, Ley general de cooperativas. Vol. 3, artículos 67 al final. Madrid: Edersa.

Vicent Chulià, F. (2002a). Introducción al Derecho Mercantil. Valencia: Tirant lo Blanch.

Vicent Chulià, F. (2002b). Variaciones mercantiles sobre responsabilidad civil de los administradores y auditores en vísperas de la unificación concursal. DN, 114(septiembre).

Vicent Chulià, F. (2002c). El futuro de la legislación cooperativa. CIRIEC, Revista Jurídica de Economía Social y Cooperativa, 13(octubre).

Vicent Chulià, F. (2003). La Sociedad Cooperativa Europea. CIRIEC, Revista Jurídica de Economía Social y Cooperativa, 14(octubre).

Vicent Chulià, F. (2005). Introducción al Derecho Mercantil. Valencia: Tirant lo Blanch.

Vicent Chulià, F. (2008). Tres años de Ley concursal: temas de reforma. RCP, 8.

Vicent Chulià, F. (2010). Las misiones del Derecho mercantil en el siglo XXI. En J. A. Gómez Segade y García Vidal, A. (Eds.). El Derecho mercantil en el umbral del siglo XXI. Libro homenaje al Prof. Dr. Carlos Fernández Nóvoa en su octogésimo cumpleaños. Madrid, Barcelona, Buenos Aires: Marcial Pons.

Vicent Chulià, F. (2012). Introducción al Derecho mercantil. Valencia: Tirant lo Blanch. Recuperado de: www.tirantonline.com. 